\title{
Does patient empowerment matter in building loyalty?
}

\author{
Amrul Asraf Mohd-Any ${ }^{1}$ (D) | Meenatharisni Sundramohana ${ }^{2} \mid$ Moniruzzaman Sarker $^{3}$ (C)
}

${ }^{1}$ Department of Marketing, Faculty of Business and Accountancy, University of

Malaya, Kuala Lumpur, Malaysia

${ }^{2}$ Marketing and Corporate Communications Office of a Leading Private Healthcare Group in Malaysia, Kuala Lumpur, Malaysia

${ }^{3}$ Department of Marketing, Sunway University Business School, Sunway University, Subang Jaya, Malaysia

\section{Correspondence}

Amrul Asraf Mohd-Any, Department of Marketing, Faculty of Business and Accountancy, University of Malaya, Kuala Lumpur, Malaysia.

Email:amrul_asraf@um.edu.my

Moniruzzaman Sarker, Department of Marketing, Sunway University Business School, Sunway University, Subang Jaya, Malaysia.

Email:mrajib.sarker@gmail.com

\begin{abstract}
Patient empowerment is becoming an essential tool for improving patient-doctor relationships in the healthcare sector. Past research on empowerment within this sector has focused primarily on hospital staff such as nurses and practitioners, whereas very few studies have focused on patients. Moreover, even less attention has been paid to exploring the effect of patient empowerment on patients' trust in doctors, patient-doctor relationship commitment and patient loyalty. Hence, we investigate the relationships between patient empowerment components (patient education, patient perceived control, doctor support and patient participation), patients' trust in doctors and patient-doctor relationship commitment, which leads to the desired state of patient loyalty. Using hospital-intercept surveys, 234 responses were obtained from patients at a private healthcare facility in Kuala Lumpur, Malaysia. Using partial least-squares structural equation modelling (PLS-SEM) techniques, the results demonstrated that patients who were empowered through education and doctor support were more trusting and that such empowerment also fostered relationship commitment towards their doctor. Patient participation and patients' perceived control did not produce similar outcomes. Consequently, relationship commitment was found to be the dominant predictor in building patient loyalty. This study broadens the dimension of patient empowerment by adding patient education, which is shown to have a positive impact on patient-doctor relationships and to promote patient loyalty. In an increasingly competitive healthcare market where patient loyalty is highly sought after, these findings suggest that empowering patients during healthcare consultation is conducive to the building of long-term relationships between patients and their doctors.
\end{abstract}

\section{KEYWORDS}

healthcare service, loyalty, Malaysia, patient education, patient empowerment, trust

\section{1 | INTRODUCTION}

Although studies on empowered employees have produced valuable conclusions, in recent years, scholars have explored the flip-side of service experience through customer empowerment. Scholars and practitioners have urged service-focused firms, such as healthcare providers, transportation companies, hospitality services and financial institutions to drive towards developing long-term relationships with their customers and building loyalty (Lai \& Chong, 2020; Morgeson et al., 2020). Central to this view, service organisations can capture greater customer loyalty and therefore more profitable relationships over time by empowering their customers with tailor-made services (Evanschitzky et al., 2012; Morgeson et al., 2020). Managing customer relationships effectively through customer empowerment drives greater customer benefits, such as customised outcomes, experiential value, utilitarian gain and satisfaction (Auh et al., 2019). This emerging 
trend is apparent in financial services (Brennan \& Coppack, 2008; McShane \& Sabadoz, 2015) and hospitality (Pranić \& Roehl, 2013).

Empowerment as a guiding paradigm has also gained currency in the medical care industry. Healthcare players are increasingly recognising patient empowerment as a key element for realising a collaborative patient-doctor relationship (Cox et al., 2003; Ippolito et al., 2019), which is innately co-produced. In fact, patient empowerment is now recognised as an integral aspect of high-quality patient-centred healthcare, resulting in satisfactory outcomes and clinical results (Chen et al., 2016). Principally, the co-production concept here refers to the synergy between consumer and provider in the design and delivery of services, which maximises customers' experiential value and leads to superior customer relationship and loyalty (Palumbo, 2016; Voorberg et al., 2015). Co-production requires active collaboration between patients and doctors to create value and build patient loyalty. Hence, building patients' loyalty to their doctors ultimately functions as a profitable scheme for medical care service providers (Gabay, 2016). In the same vein, Meesala and Paul (2018) advocate that due to subsisting value co-production mechanism in medical care services, patients build trust in physicians, which in turn create loyalty. However, intense competition could potentially erode a company's market share and strain operating margins and profitability. For example, Malaysia runs on a dichotomous public-private healthcare system (Quek, 2014). Once a largely government-led service, the healthcare sector has transformed into a dual-tiered system with a booming private sector since the introduction of the Private Healthcare Facilities and Services Act 1998 (Nawawi, 2012). The Edge Markets, together with Frost and Sullivan, reported that by 2020, Malaysia's healthcare industry spending would reach RM80 billion, compared to RM52 billion at the end of 2017 (Zainul, 2018). In this expanding national healthcare market, accompanied by a growing number of private healthcare facilities in the country, competition becomes inevitable as customers are spoilt for choice. As a result, the private healthcare sector has become greatly concerned with building patient loyalty and cultivating relationships between patients and their doctors at particular hospitals.

Even though patients play an integral role in the value cocreation process of medical services, their mere presence during healthcare consultation alone is often inadequate to maximise the value of the service experience. Most medical conditions require a substantial level of management and therefore also require patient empowerment in a collaborative patient-doctor relationship. Similarly, Paul and Sahadev (2018) assert that factors which nurture value co-creation environment within an organisation account for favourable performance of elderly care homes. Ippolito et al. (2019) noted that empowerment goes beyond what proactive involvement and customer satisfaction consist of in a healthcare setting. In one moment, patients can feel empowered, and in another, they may not. Thus, it is imperative to understand that in patients' trajectories, their interactions with doctors may determine their feelings of empowerment and/or disempowerment. Previous studies (see Alicia et al., 2020; Clark, 2014; Ippolito et al., 2019; Laine et al., 2019; Stenberg et al., 2019; and Yajnik et al., 2018) acknowledged patient education (also referred to as provider-patient communication) as one of the central aspects of patient empowerment that has been given considerable attention in the extant literature. However, empirical understanding of the effect of patient education on cultivating patient-doctor relationship and patient loyalty is limited.

Ouschan et al. (2006) found that patient empowerment dimensions (i.e., patient's perceived control, doctor support and patient participation) positively impacted patient trust and commitment toward their physicians. However, very limited studies have measured the impact of patient empowerment during healthcare consultation, especially through loyalty evaluations. Moreover, the absence of patient education in conceptualising patient empowerment presents a new avenue to understand medical service behaviour that has also been overlooked in previous studies. In the Malaysian context, extant research (see Afthanorhan et al., 2017; Aliman \& Mohamad, 2016; Aljumaha et al., 2020; Rahman et al., 2018; Tan et al., 2019) has been mostly devoted to investigating medical service quality components, patient satisfaction and patient loyalty. Studies pertaining to patient empowerment and patient loyalty to doctors, in particular, have been largely disregarded. Given the importance of patient education (Alicia et al., 2020; Ippolito et al., 2019) and loyalty in building a long-term patient-doctor relationship (Lai \& Chong, 2020; Torres et al., 2009; Zhou et al., 2017), there is a need for further research on the comprehensive role of patient empowerment in building patient loyalty. Our study seeks to extend the existing literature by not only examining the impact of patient empowerment on trust and relationship commitment, but also on the outcome of patient loyalty. As loyal customers are inclined to spend more, express higher purchase intentions and resist switching brands (Evanschitzky et al., 2012), the creation and maintenance of such patient loyalty would help practitioners to develop a mutually beneficial relationship with their patients. This study also broadens the patient empowerment dimension through the addition of the patient education construct. Therefore, the purpose of this study is to explore the impact of patient empowerment dimensions during healthcare consultation (patient's perceived control, doctor support, patient participation and patient education) on patient-doctor relationship (i.e., patient trust in doctor and relationship commitment), leading to the desired state of patient loyalty.

The remainder of this article is structured as follows. The next section presents our literature review, which helps to highlight the research gap and assists in the development of the hypotheses. The following section explains the methodology and results of the study in terms of how the data were collected and analysed. This article ends with a detailed discussion on theoretical and managerial implications, followed by directions for future research and conclusion.

\section{LITERATURE REVIEW AND CONCEPTUAL DEVELOPMENT}

\section{1 | Empowerment theory}

The concept of empowerment is rooted in the 1960's ideology of 'social action' as well as the 1970's perspective of 'self-help' (Aujoulat 
et al., 2007). At an organisational level, structural empowerment theory was construed by Kanter (1977), who conceived power as the ability to gather information, resources and support to facilitate performance. In many ways, management plays an important role in providing their workforce with the tools to maximise their talents and accomplish their tasks in a meaningful way (Spence Laschinger et al., 2010). Zimmerman (2000) developed one of the most widely used theories on empowerment. In this regard, he defined empowerment as two or more individuals' determination over one's own life, enabling effective participation whereby people, communities and organisations gain mastery over their affairs. This theory of empowerment fundamentally includes processes where opportunities to increase capabilities, practice skills, exert control and influence decisions are recognised (Zimmerman et al., 2011). This theory, which captures the psychological aspect of empowerment, has since been used in several studies (Bulsara \& Styles, 2013; Christens et al., 2011; Van Den Berg et al., 2013). The concept of empowerment also suggests that when consumers are better equipped with ample knowledge and autonomy, they can exercise control over their health management decision (Camacho et al., 2014; McShane \& Sabadoz, 2015). Thus, information sharing is not the only way to identify consumers' problems; discussions between providers and consumers regarding alternative solutions and courses of action may yield better results.

The idea of patient empowerment was first conceptualised by Feste and Anderson (1995). In this regard, they noted that empowerment is a viewpoint hinging on the belief that, to be healthy, people should be able to make changes not only to their behaviour, but also to social situations that influence their lives. Ippolito et al. (2019) articulated that patient empowerment is a complex process in which patients and providers co-produce the value of their healthcare service-related action and decision-making. This implies that patient empowerment gives patients the opportunity to make informed and healthier choices (Ben Ayed \& El Aoud, 2017) and the outcomes they would most prefer (Rohrer et al., 2008). Patients also need to act on aspects that affect their conditions in order to achieve well-being. An example would be a patient following their doctor's diet recommendation in the treatment of gastro symptoms. Furthermore, the definition put forward by Gibson (1991) supports not only these assessments but also the notion of control as a part of empowerment. Assessing another description of empowerment specified by Tengland (2008), we argue that empowerment is fundamentally a relational concept. Patients can only be empowered if healthcare professionals present them with opportunities to become empowered. Hence, it is essential to take into account the 'power balance' between patients and doctors to fully capture empowerment. During healthcare consultations, patients are expected to participate by being present and by providing information about their condition, how they feel and their preferences for treatment. When patients receive diagnoses of lifelong chronic diseases, they must often make major changes in their lives. Not only do they need to broaden their understanding of the condition and its treatment, but they are also usually advised to integrate a number of lifestyle changes into their day-to-day life. These changes may include a healthy eating regimen, regular exercise, taking medication dutifully and many others (Ben Ayed \& El Aoud, 2017). Integrating such activities into daily life calls for change at the behavioural as well as at psychological levels (Aujoulat et al., 2007). Thus, patients cannot be limited only to simple practical actions but rather must be involved in the outcome of a dynamic process of empowerment. Likewise, doctors must play an important role in educating and supporting their patients.

Building on Ouschan et al.'s (2006) proposed model of patient empowerment dimensions, which is relevant from a medical perspective-and further supported by campaigns on patient empowerment by The World Health Organization (WHO) (2009) and the European Patients' Forum (2015) Strategic Plan 2014-2020-our study broadens the patient empowerment conceptualisation and examines it from the following perspectives: (i) patient's perceived control over illness; (ii) patient's participation during consultation and medical decision-making processes; (iii) patient's perception of education during medical encounters; and (iv) doctor's support received during consultation and treatment. Empowering patients during patient-doctor consultations will also enhance patients' trust inand commitment to-their doctors, which should in turn be associated with increased patient loyalty toward their doctor (Moreira \& Silva, 2015).

\subsection{Patient education, patient trust in doctor and patient commitment}

Broadening consumer knowledge has been shown to be a valuable augmentation at the core of any service offering (Bell et al., 2017). In service industries, awareness of relevant information concerning the service offerings and processes helps consumers in framing service perceptions (Eisingerich \& Bell, 2008). Depending on the nature of the product or service, customers may receive information through various educational channels, such as professional advice, advertisement, editorial and online tools (Suh et al., 2015). McNeal (1978) noted that companies should focus on customer education as one of their major competitive strategies. This focus on customer education serves at least three purposes: first, companies will be able to attain and retain satisfied customers, thereby bringing about favourable attitudes towards a product; second, increased customer education is conducive to beneficial outcomes, thereby leading to larger profits; and finally, even the mere appearance of such a focus on customer education may reduce confrontation with consumer activists. Product knowledge can certainly help consumers understand the full specification, tackle any issues that may arise and move on to a better and more sophisticated version of the product (Bell \& Eisingerich, 2007). Ironically, despite these beneficial outcomes, Fodness et al. (1993) argued that when customers no longer require the understanding of a product, their perceived switching cost is reduced, giving them the luxury to seek alternatives. However, Eisingerich and Bell (2008) later discovered that, in the context of financial services, customer education had a significant, direct and positive effect on consumer 
trust. Customers are more likely to view their service providers as trustworthy when education is rendered. It is undeniable that the lack of tangibility presented in services-as opposed to physical products whose inherent quality may be more readily perceived-makes trust-building more of a challenge (Mittal, 1999). In healthcare provisions, the nature of medical treatments, surgeries and doctor's advice is highly intangible and inseparable, which often make them difficult to be evaluated, even after consumption, or also known as credence services (Shostack, 1982). Through the explanation of concepts and by providing critical information, service providers can provide a level of understanding and clarity to their customers that could, in turn, facilitate the building of trust relationships between customers and service employees (Suh et al., 2015).

As a mechanism for empowering patients in the healthcare industry, education refers to the process by which clinicians impart medical knowledge in the best interests of their patients (Jotterand et al., 2016). Patient education is also emphasised as the nucleus of health and social care services (Alicia et al., 2020; Clark, 2014). Hence, we conceive of patient education as the extent to which doctors explain medical concepts and terms to their patients, such as the extent to which the benefits and side effects of such treatments are indicated (Sharma \& Patterson, 1999). Limited knowledge of such medical concepts and terms may be detrimental to patients' health management. Sufficient knowledge and a deep understanding of one's medical condition, risks and healthy behaviour are important to prevent potential complications over time. Effective communication between provider and patient expedites overall healthcare experience and enhances patient confidence and commitment to healthcare service providers (Cox et al., 2003; Hare et al., 2013). When patients are given the correct medical diagnosis, they become more aware of their conditions; this empowers them to make more informed choices about their health (Bonsignore et al., 2015). This knowledge will further encourage them to ask more questions and take greater responsibility for their health, which indicates patient education as one of the most important components of empowerment (Mcguckin et al., 2011). When customers gain knowledge, their level of trust in their service providers also increases (Suh et al., 2015; Yin \& Yang, 2009). Furthermore, scholars have stated that patient education serves to strengthen relationship commitment (Berry et al., 2008; Sharma \& Patterson, 1999). Based on the studies highlighted above, we posit that:

Hypothesis 1 Patient education positively affects: (a) patient trust in doctor and (b) relationship commitment towards the doctor.

\section{3 | Patient perceived control, patient trust in doctor and patient commitment}

Individual involvement in health-promoting behaviours has long been studied by health psychologists, with health perception as one of its main drivers (Gabay, 2015). Zimmerman's wide-ranging definition indicated that psychological empowerment embodies intrapersonal, interactional and behavioural components. When narrowed down to the behavioural dimension of psychological empowerment, it indicates the degree to which a person can take control and proactively adapt to challenges (Ben Ayed \& El Aoud, 2017). Generally, perceived control refers to 'the belief that one can determine one's internal states and behaviour, influence one's environment and/or bring about desired outcomes' (Wallston et al., 1987, p. 5). The broad theoretical foundation of perceived control embodies components such as locus of control, self-efficacy and mastery (Kozela et al., 2017).

In the healthcare setting, patients' perceived control over their illness management behaviour helps them to recover effectively. While an authoritative or one-sided relationship may be well suited for acute illnesses such as the common cold, fever and mild physical pain, such a dynamic is inappropriate for the treatment of chronic medical conditions. For patients with long-term chronic illnesses such as diabetes, heart and lung diseases or cancer, symptom management is increasingly becoming the responsibility of patients (Stenberg et al., 2019). Characteristically, empowered patients are those who have control over the management of their illnesses (Bonsignore et al., 2015). In this regard, the WHO strongly advocates for patients to be more involved by developing a greater sense of autonomy and taking control of their health and the management of their condition (Hoffman, 2013). In a study conducted on three Eastern European populations, Kozela et al. (2017) concluded that patients with low perceived control had increased risk of cardiovascular disease incidence and mortality.

At the same time, doctors have an equally important role to play in helping patients take control of their medical conditions. While perceived control impels patients to positively believe in their capacity to make healthier choices, it also elicits their expectations of their doctor. Patient's feelings of comfort and assurance in taking control of their health care enhance the level of trust and commitment they have for their doctor. Gabay (2015) discovered that patient perceived control has a direct positive effect on patient-doctor relationship (i.e., trust and commitment). This finding shows that when doctors engage in a conversation with their patient regarding their expectations of best care, the likelihood of dissatisfaction is minimised, which eventually increases trust and commitment toward that doctor. Ouschan et al. (2006) also reported a positive significant impact of patient perceived control on both patient trust and patient commitment to the doctor. This leads to the following hypotheses:

Hypothesis 2 Patient perceived control over their medical condition positively affects: (a) patient trust in doctor and (b) relationship commitment towards the doctor.

\section{4 | Doctor support, patient trust in doctor and patient commitment}

Doctor support remains a cornerstone of medical care and has been the subject of extensive philosophical, sociological and 
literary attention over the decades. Certainly, healthcare professionals must play active roles if patient empowerment is to be realised (Chatzimarkakis, 2010). This, therefore, calls for an interactive and productive dialogue between patients and doctors. While patients take active control of their health, doctors, on the other hand, must build a relationship that meets patient expectations. Such relationship building can be achieved by offering autonomy support and actively involving the patient in decision-making. Autonomy support, as emphasised in our research, is the process by which doctors provide effective treatment options, emotional support, and consider patients' opinions and efforts (Schmidt et al., 2012). Patients also feel empowered when their doctors are responsive, understanding, caring and even 'go the extra mile' by encouraging their patients to ask questions (Gensichen et al., 2009). All these elements constitute the key value of empathy, which is an essential element in the patient-doctor relationship.

The way in which service providers communicate with their customers also influences both customer trust and relationship commitment. For example, Birkhäuer et al. (2017) discovered that from a clinical standpoint, patients usually adopt beneficial health behaviours and have higher quality of life when higher levels of trust are attached to healthcare professionals. Many patients have also emphasised the relevance of interaction and the pertinence of having a doctor who would listen to them and who follows patientcentred approaches. This nature of the patient-doctor relationship is particularly relevant for patients with long-term conditions, such as diabetes, heart disease, asthma and hypertension (Alexander et al., 2014). Due to the extensive amount of time spent together during treatment sessions or assessments, a good bond between patient and doctor will result in better-quality outcomes. Studies have shown that a stressful patient-doctor relationship leads to dissatisfaction for both parties (Matthias et al., 2010). Hence, it would be beneficial if practitioners become more actively involved in discussion of goals and treatment, as this can build trust and create a valuable relationship. Ouschan et al. (2006) also reported that doctor support is the most important determinant of patient commitment and trust. Therefore, we posit that:

Hypothesis 3 Patient-perceived doctor support positively affects: (a) patient trust in doctor and (b) relationship commitment towards the doctor.

\section{5 | Patient participation, patient trust in doctor and patient commitment}

The ultimate goal of any customer-driven business is to create and sustain a long-term, mutually beneficial relationship (Kandampully et al., 2015). Contemporary marketing views, however, suggest that being customer-oriented alone is not sufficient for a company to remain competitive. In the interest of creating value to meet customers' dynamic and individual needs, providers must adopt collaborative efforts and open up more of their processes for active participation (Chan et al., 2010). In this regard, the term customer participation is defined as the level of customer involvement during service production and delivery, to which effort, knowledge and other resources are shared in the process (Dong \& Sivakumar, 2017). Customer participation is emerging as the next frontier in competitive advantage studies (Auh et al., 2019; Chan et al., 2010). This is also consistent with Vargo and Lusch's (2004) perspective on the shift from goods-centred to service-centred approaches, which focus on value co-creation and relationships. With the introduction of service-dominant logic, practitioners and service researchers have been increasingly embracing the notion that customers are proactive co-creators instead of passive receivers of value, and in response, firms are facilitating the value co-creation process (Vargo $\&$ Lusch, 2004, 2016). The concept of value co-creation is particularly salient amongst high-contact professional services that are high in credence properties (Chan et al., 2010) such as legal, healthcare, consulting and financial services. Studies on participation in the financial service industry, for instance, demonstrate that when customers contribute by providing information and mutually make decisions about their investment plans alongside their financial advisors, their loyalty is greatly increased (Auh et al., 2007; Eisingerich et al., 2014). Yin and Yang (2009) also demonstrated that customer participation had a significant impact on trust in restaurant services.

Likewise, the natural equivalent of customer participation-that is, patient participation-is not an unheard-of concept in the healthcare industry and is of particular importance during consultation service encounters. When patients are presented with the opportunity to co-create value during healthcare consultations with their doctors, they are encouraged to share crucial information. Such behaviours include describing current symptoms experienced, cooperating during diagnostic procedures, discussing treatment options and openly expressing concerns or desires to proceed with specific therapies (Gallan et al., 2013). Supporting this notion, Ouschan et al. (2006) also found that patient participation had a positive impact on trust and commitment toward the doctor. Based on the rationale above, there is reason to believe that:

Hypothesis 4 Patient participation during healthcare consultation positively affects: (a) patient trust in doctor and (b) relationship commitment towards the doctor.

\subsection{Patient trust in doctor and patient loyalty}

Trust has been recognised as one of the fundamental factors for preserving continuity in customer-provider relationships (Chiu et al., 2012). Han and Hyun (2015) defined trust as a customer's willingness to rely on others as well as their expectations concerning the reliability of a service provider. Trust is also the customer's belief that a product or a service will perform in such a way that their long-term interest will be met (Martínez \& del Bosque, 2013). Researchers in the hospitality industry have categorised trust as either credibility trust or benevolence trust (Sirdeshmukh et al., 2002). 
Credibility trust refers to the confidence in the capabilities of a firm to deliver a good-quality service as expected by the public (Martínez $\&$ del Bosque, 2013), whereas benevolence trust is the confidence that the provider will extend a trustworthy and competent service while also displaying concern, care and honesty (Kiyani et al., 2012).

Examining the impact of service recovery in the banking industry, Dos Santos and Basso's (2012) findings revealed that trust built between satisfied clients and employees played a crucial role in clients' intention to spread positive word-of-mouth. Intentions to repurchase a product are also significantly affected by the level of customer trust (Chiu et al., 2012). Because medical tourism is one of the most lucrative health sectors in some countries-including Malaysia (Habibu, 2020), a higher level of trust in care providers and medical professionals increases the likelihood that international patients will return to the country (i.e., loyalty intention) for future treatments and consultations (Han \& Hyun, 2015). Similarly, in an industry such as healthcare, where perceived risks are high and lives may be at stake, trust becomes an essential element. The relationships between patients and doctors rely heavily on trust built over time. As a consequence, patients' belief that their well-being takes precedence, and they expect that the best treatment options will be rendered to them. When patients perceive their doctors to be sincere, credible, honest and benevolent, trust will naturally exist in the relationship built (Berry et al., 2008). Previous studies such as Gabay (2016), Moreira and Silva (2015) and Zhou et al. (2017) further attested that healthy and trustful relations between patients and doctors-especially in the private healthcare setting-can help retain existing patients. Hence, we further hypothesise that:

Hypothesis 5 Patient trust in their doctor positively impacts patient loyalty.

\section{7 | Relationship commitment and patient loyalty}

From a behavioural standpoint, loyalty represents the extent to which customers engage in repeat purchase behaviour, whereas relationship commitment explicates the level of psychological bonding attached to a particular brand or objects. In healthcare services, patients are highly involved during consultations with their doctors. Compared to the behaviours of customers from other service industries, patient behaviour differs because it is determined by several unavoidable factors, such as the nuances of specific medical conditions and the severity of their illnesses (Astuti \& Nagase, 2014). Generally, patients do not have many options in terms of diagnosis, quality of treatment and medication prescribed; hence, their choice is based on the nature of the patient-doctor relationship. In many ways, potential avenues by which doctors can meet patients' expectations and cultivate loyalty have been discussed extensively (Huang et al., 2019; Lai \& Chong, 2020; Moreira \& Silva, 2015; Torres et al., 2009; Zhou et al., 2017). From a patient's point of view, relationship commitment and trust in one's doctor are fundamental antecedents to the patient-doctor relationship (Torres et al., 2009).
In the absence of trust and relationship commitment, switching behaviour can be triggered, thus weakening loyalty. Moreira and Silva (2015) have demonstrated that trust and relationship commitment in healthcare providers increases patients' willingness to display loyalty. To unite service providers with like-minded patients, it is important to tailor and design personalised experiences to co-create value, eventually enhancing loyalty (Astuti \& Nagase, 2014; Suki, 2011).

Relationship commitment is defined as the weight of a valued relationship. It is the consumer's credence in maintaining the relationship and willingness to continue investing energy toward its longevity in the hopes of generating functional and emotional gains (Berry et al., 2008). Generally, if a relationship is believed to be important, parties will make an effort to sustain it (Morgan \& Hunt, 1994). The feeling of being committed to a relationship is stronger and more robust than a person's general attitude toward a favourite brand. In a medical care setting, patients who are in a committed relationship with their doctors will naturally continue to sustain that bond (Moreira \& Silva, 2015). In the same study, Moreira and Silva also observed that, despite the strong correlation between them, loyalty and commitment are distinct concepts-even though, at times, commitment and loyalty may be substituted for one another. Indeed, Oliver (1999) claims that loyalty is composed of three phases-Phase 1: cognitive (i.e., belief derived from past or recent experience-based knowledge of a product or brand), Phase 2: affective (i.e., attitude or likeability derived from usage of a product or brand) and Phase 3: conative (i.e., behavioural commitment through re-purchase intention)-in the second phase, commitment refers to affective loyalty. Iglesias et al. (2011) substantiated that commitment is a different construct from brand loyalty, and in fact, commitment (affective phase) is the key determinant of behavioural loyalty (conative phase). This notion explains that as an individual's commitment increases, so does their loyalty towards a brand.

A well-nurtured relationship between providers and beneficiaries is one of a company's profitable intangible assets, which functions as a mechanism of creating customer loyalty. When a patient achieves a beneficial outcome from their preferred medical care provider that is superior to what they might have obtained from competing providers, they may express a willingness to pay more (Allender \& Richards, 2012) as well as remain loyal (Suki, 2011). By encouraging the development of such high-quality relationships between patient and doctor, private healthcare providers can retain existing patients and attract new ones. As Torres et al. (2009) demonstrated, committed patients forge emotional attachments with their preferred service providers, which in turn leads to loyalty. Research on hospital marketing has also highlighted the significance of relationship commitment and the effect it has on patients' loyalty to their doctors (Kim et al., 2008). Scholars such as Lai and Chong (2020) and Zhou et al. (2017) posited that relationship commitment has a direct and positive effect on a patient's loyalty to their doctor. Thus, we hypothesise that:

Hypothesis 6 Patients' relationship commitment positively affects patient loyalty.

Figure 1 shows the conceptual model of the study. 
FIGURE 1 Research model

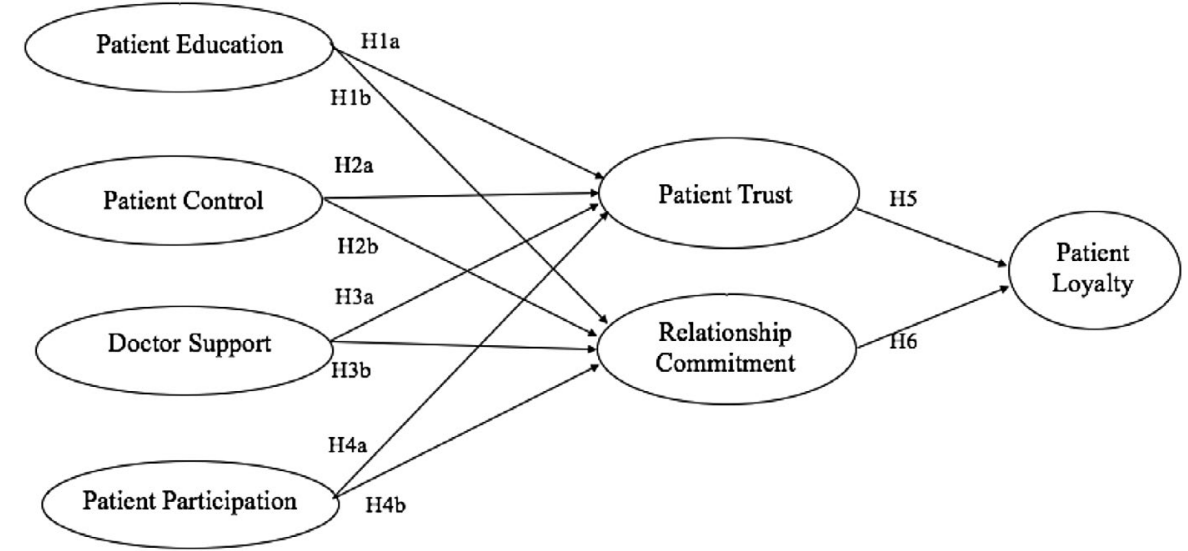

\section{3 | METHODOLOGY}

\section{1 | Data collection method}

Previous studies in patient empowerment and medical care experience adopted an experimental approach by using mail survey techniques. However, these methodologies have their shortcomings. Given the fact that recollections of service experience are never the same as the actual encounters, mail survey methods usually lack accuracy and conscientious response (Wen \& Geng-qing Chi, 2013). Thus, to overcome these inadequacies, we proceeded with realtime, on-the-spot investigation-an approach previous studies have not taken. In past studies-as seen in Ouschan et al. (2006) and Small et al. (2013) - questionnaires have been mailed (i.e., email survey) to the participants registered in chronic illnesses association. Departing from this approach, we adopted a face-to-face survey data collection technique instead with patients waiting at the outpatient clinics.

\section{2 | Sampling and data collection}

Data were collected from outpatient clinics at Springsteen Medical Centre $^{1}$ in Kota Damansara (a suburb just outside the city of Kuala Lumpur, Malaysia) and were disseminated using a nonprobability purposive sampling method. A leading private hospital, the 200-bed Springsteen Medical Centre, employs more than 100 surgical doctors spanning over 50 medical specialties. Information was gathered from patients of a single hospital to help us control for confounding aspects of organisational differences such as varying talent pools of doctors amongst institutions (Seibert et al., 2016). Prior to data collection, the instrument was validated through expert-driven pretesting (Jansen \& Hak, 2005) conducted by one experienced researcher and senior academic in the marketing department of a public university in Malaysia. The hospital's chief executive officer (CEO) and the Medical and Dental Advisory Committee (MDAC) also examined the questionnaire to verify that potential responses would not disclose patients' private medical information. Some items were slightly reworded based on feedback from the pretest.

To estimate the sample size, we performed a statistical power analysis using the G*Power 3.1 software (Faul et al., 2009) with the following settings: effect size $f^{2}$ value of $0.15, \alpha$ of 0.01 , power of $95 \%$ and a total of 4 predictors; the minimum recommended size generated was 169. A total of 234 respondents completed the survey over 3 weeks. Given that data collection was closely supervised, no missing values were reported. Therefore, the 234 final usable responses were more than adequate to meet the power requirements. This sample size is also adequate considering the challenges involved with collecting data in a clinical setting; for instance, some patients-especially those in the early stages of diagnosis-may not be at peak health and emotions may be running high. Such patients may be triggered by anxiety and fear of the unknown as reported by NBC News Wellness (Gould, 2017). Hence, it is reasonable for some patients to feel reticent about sharing their experiences and thoughts.

Respondents were identified and approached during clinic waiting time, strictly targeting only those patients who had consulted the same doctor at least twice. The patients themselves verified that they satisfied this mandatory requirement before we distributed questionnaires to them. To further affirm this precondition, subjects' information was double-checked at the registration counter to verify that they had indeed consulted with the same doctor twice or more. This criterion is significant because patients who visit the same doctor repeatedly have a better understanding of their relationship status, given the time already spent together during previous consultations. Information was gathered on the spot from respondents at the clinic, immediately following doctor consultations-an approach that previous studies did not use. This improves data accuracy because patients' experiences are still fresh in their minds. Each respondent was required to sign a consent form, and the research setting was closely monitored and controlled to ensure that the Malaysian Personal Data Protection Act 2010 (PDPA) was not breached.

${ }^{1} \mathrm{~A}$ fictitious name to maintain anonymity. 


\section{3 | Measurement}

All measures were derived from past literature and modified to suit our study context. In measuring patient empowerment, we adapted and built upon Ouschan et al. (2006) proposed dimensions of patient participation and patient perceived control. Patient participation was measured using eight items, as was patient perceived control. To capture patient education, four items were taken from Eisingerich and Bell (2006). For the final patient empowerment dimension, doctor support was assessed based on a modified version of the Health Care Climate Questionnaire (HCCQ) which consists of 14 items (Schmidt et al., 2012). Next, we measured relationship commitment using five items from Torres et al. (2009) and four items for patient trust in doctor from Suh et al. (2015). Finally, we operationalised patient loyalty as an overall attitudinal loyalty towards a specific doctor that results in repeat visits, also adapting three items from Chang et al. (2013). All measures were anchored on a 7-point Likert-type scale, ranging from either $1=$ Extremely Disagree to $7=$ Extremely Agree, or 1 = Very Unlikely to 7 = Very Likely. Appendix 1 shows the list of measurement items used in this study.

\section{4 | RESULTS}

As the structural theory of our study contains multiple variables and relationships between the variables (which are presented according to the posited hypotheses), the structural equation modelling (SEM) technique is highly relevant to examine the theoretical framework (Hair et al., 2014). Hence, when estimating the proposed framework, it is important to choose a suitable SEM technique between a covariance-based SEM (CBSEM) and a variance-based SEM (VB-SEM) (also referred to as partial least-squares (PLS-SEM)). We began by assessing the data for multivariate normality (Cain et al., 2017; Hair et al., 2017) via an online software called WebPower. The results revealed that our data were not normally distributed through the Mardia's multivariate skewness $(\beta=20.39$, $p<.01$ ) and Mardia's multivariate kurtosis ( $\beta=114.25, p<.01$ ) readings. Moreover, with more than six constructs to be estimated, our conceptual model is considered a complex model (Hair et al., 2017). The model intends to predict the key construct of patient loyalty on a statistical basis. Therefore, based on these initial conditions of (1) multivariate nonnormal distribution, (2) model complexity and (3) prediction-oriented modelling, a nonparametric analysis via the PLS-SEM methodology with SmartPLS 3.2.9 software (Hair, Hollingsworth, et al., 2017; Hair et al., 2017; Manley et al., 2020) was deemed suitable along with SPSS v.23 for descriptive statistics and other related procedures. Overall, the sample consists of nearly equal proportions of male and female respondents who are mostly between the age of 26 to 45 years. Table 1 presents the demographic profile of the respondents in detail.

\section{1 | Measurement model}

We first tested the reliability and validity of the measures by calculating the algorithm in SmartPLS 3.2.9 (Ringle et al., 2015). Item loading of 0.708 or higher is recommended; anything below is adequate only if other items demonstrate high loadings to complement the average variance extracted (AVE) and composite reliability (CR) (Ramayah et al., 2018). Table 2 shows that most items were above these thresholds, suggesting satisfactory item reliability. To test for internal consistency of the constructs, we examined the CR and AVE values (Fornell \& Larcker, 1981; Hair \& Sarstedt, 2019). CR estimations above 0.70 and AVE values above 0.50 are considered to support internal consistency (Hair \& Sarstedt, 2019). As seen in Table 2 , all estimates exceed the specified criteria, demonstrating internal consistency. However, conforming to the criteria indicated above, items for patient participation PP1 (0.622), PP3 (0.175) and PP4 (0.521) were removed. Next, because half of the total items from patient perceived control would be potentially deleted due to low loadings and poor AVE and CR, we decided to inspect the cause of this phenomenon. Scale purification literature cautions that if the process of eliminating reflective items is performed carelessly, it may impair the measurement properties and parsimony of the construct involved (MacKenzie et al., 2011; Wieland et al., 2017). Therefore, by further examining patient perceived control through exploratory factor analysis (EFA) in SPSS v.23, we uncovered two separate components, thereby demonstrating a multidimensional construct. When a construct has several distinct but related dimensions viewed as a single concept, the construct is said to be multidimensional (Hair et al., 2010). Therefore, in support of extant research, we named the two components self-efficacy and locus of control, respectively (Claassens et al., 2014; Kozela et al., 2017; Skinner, 1996; Wallston et al., 1987). As a higher-order measurement, patient perceived control was re-analysed following the two-stage approach in Sarstedt et al. (2019). Although the AVE of self-efficacy at the primary stage was only marginally acceptable (AVE $=0.493$ ), it demonstrated a satisfactory level of reliability and convergent validity when analysed as a subdimension of patient perceived control. Hence, none of the items was deleted from the two lower-order constructs of patient perceived control, that is, self-efficacy and locus of control (see Table 2).

Traditionally, the Fornell-Larcker criterion (FL) (Fornell \& Larcker, 1981) was used to investigate the discriminant validity between latent variables. However, studies have shown that FL demonstrates poor performance (about 23\% efficacy) compared to the heterotrait-monotrait ratio of correlations criterion (HTMT) (with more than 99\% efficacy) when confirming discriminant validity (Henseler et al., 2015). Therefore, we employed the HTMT criterion to evaluate the discriminant validity of our constructs, which is in line with PLS-SEM standards. Generally, discriminant validity is assessed in one or both of the following ways: (1) using HTMT threshold of 0.90 when constructs in the model are conceptually close and/or (2) using an HTMT-based inference test by observing the confidence interval values, which should not exceed 1.0 (Franke \& Sarstedt, 2019). The initial HTMT value of 0.94 between relationship commitment and patient loyalty revealed a state of high intercorrelations. This indicates a lack of discriminant validity between the two constructs. In other words, the constructs contain overlapping items presumed to be similar to the respondents. One way of addressing 


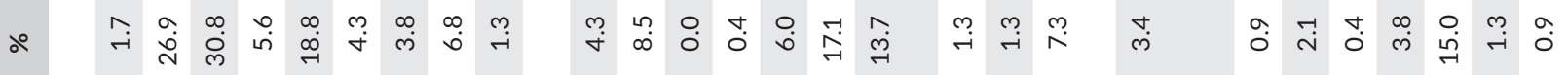

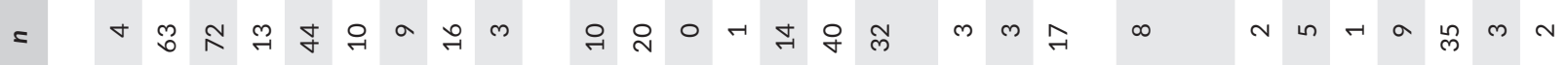

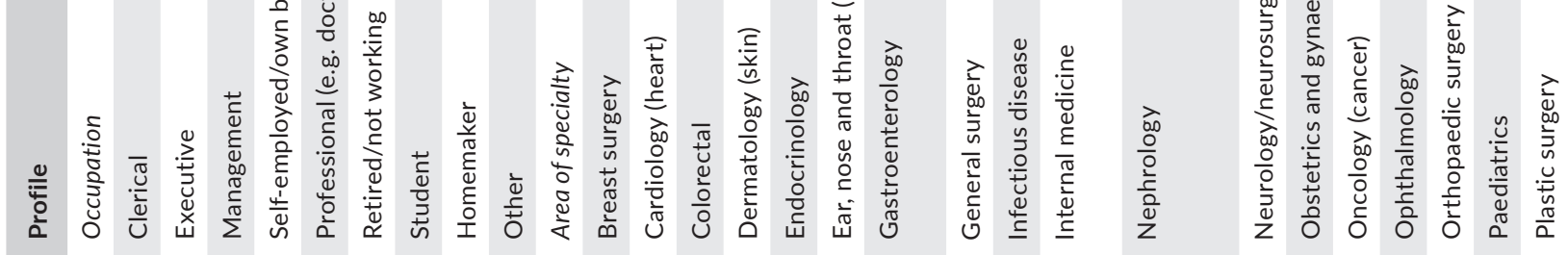

๙ $\quad$ ğ

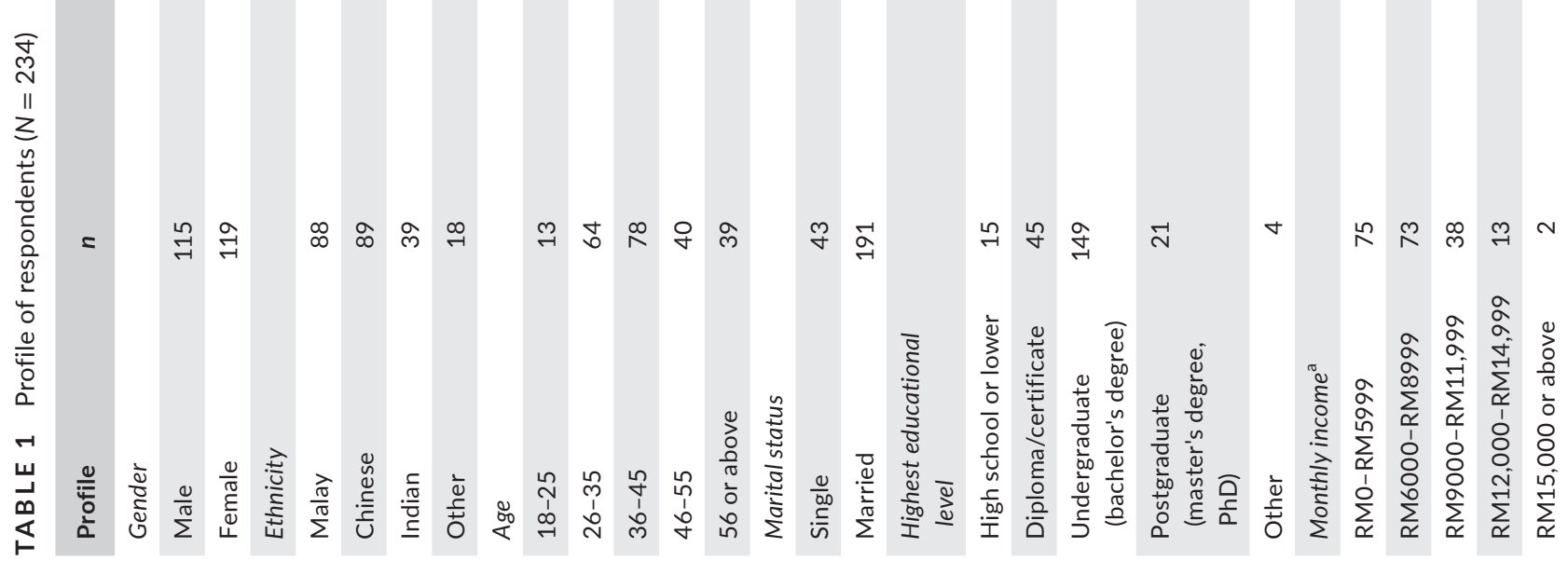


this issue is to merge the 'problematic' constructs and provide sufficient evidence from the literature to support the 'new' construct or to delete highly correlated items from the problematic constructs (Henseler et al., 2015). In this case, we deleted the two highly correlated items in the relationship commitment construct, that is, RC1 and RC5, which eventually resulted in an HTMT value of 0.897 between relationship commitment and patient loyalty, demonstrating discriminant validity of the two constructs after the item deletion process. Furthermore, all HTMT values were below 1 using the $95 \%$ bias-corrected and accelerated (BCa) confidence intervals. Table 3 shows that all of the above threshold values were met, indicating satisfactory discriminant validity (Franke \& Sarstedt, 2019; Henseler et al., 2015).

Figure 2 illustrates the modified structural model in response to changes in the results presented above.

\subsection{Common method variance}

Common method bias can lead to inaccurate results and may inflate correlations amongst latent variables, particularly because all of the constructs were measured from the same patient respondents (Podsakoff et al., 2012). To control such bias, two efforts were made to assess common method variance (CMV). Using Harman's single-factor test, we first checked whether the variance of the data was largely attributable to a single factor. The percentage variance of $39.3 \%$ was below the threshold of $50 \%$, thus indicating that CMV was not an issue (Cheah et al., 2020; Chuah et al., 2018; Fuller et al., 2016; Sarker et al., 2021). Secondly, we gauged CMV by including a theoretically unrelated marker variable in the questionnaire through the measured latent marker variable (MLMV) approach (Chin et al., 2013). The MLMV approach is recognised as one of the effective means of investigating CMV (Tehseen et al., 2017; Terho \& Jalkala, 2017), in which a marker variable has the potential to detect and reduce CMV by 70\% (Chin et al., 2013). To implement this technique, researchers are required to include in their questionnaire a construct (with its associated items) that is conceptually different or completely unrelated to the rest of the constructs in the study. This construct is then incorporated into the estimation of the structural model in order to observe the changes in $R^{2}$ values, without and with the marker variable. If significant changes are noted, there is a high possibility of CMV. In this case, a four-item workplace compensation construct by Bal et al. (2013) was included as an exogenous variable predicting the two endogenous variables of patient trust in doctor and patient loyalty. Table 4 shows the difference in $R^{2}$ values without and with the MLMV. The changes were very minute, further implying that CMV was not a concern in this study.

\subsection{Structural model and hypothesis testing}

A structural model refers to a nomological network which exhibits causal and correlational relationships amongst the variables in a 
TAB LE 2 Reliability and validity of measures $(N=234)$

\begin{tabular}{|c|c|c|c|c|c|c|}
\hline First-order constructs & Second-order construct & Items & Loadings & $\begin{array}{l}\text { Cronbach's } \\
\text { alpha }\end{array}$ & CR & AVE \\
\hline \multirow[t]{8}{*}{ Doctor support (DS) } & & DS1 & 0.663 & \multirow[t]{8}{*}{0.945} & \multirow[t]{8}{*}{0.952} & \multirow[t]{8}{*}{0.589} \\
\hline & & DS3 & 0.798 & & & \\
\hline & & DS4 & 0.743 & & & \\
\hline & & DS7 & 0.697 & & & \\
\hline & & DS8 & 0.798 & & & \\
\hline & & DS9 & 0.841 & & & \\
\hline & & DS10 & 0.839 & & & \\
\hline & & DS14 & 0.598 & & & \\
\hline \multirow{4}{*}{\multicolumn{2}{|c|}{ Locus of control (LOC) }} & PC1 & 0.819 & \multirow[t]{4}{*}{0.666} & \multirow[t]{4}{*}{0.802} & \multirow[t]{4}{*}{0.509} \\
\hline & & PC2 & 0.823 & & & \\
\hline & & PC3 & 0.601 & & & \\
\hline & & PC4 & 0.572 & & & \\
\hline \multirow{4}{*}{\multicolumn{2}{|c|}{ Self-efficacy (SE) }} & PC5 & 0.710 & \multirow[t]{4}{*}{0.658} & \multirow[t]{4}{*}{0.795} & \multirow[t]{4}{*}{0.493} \\
\hline & & PC6 & 0.573 & & & \\
\hline & & PC7 & 0.647 & & & \\
\hline & & PC8 & 0.579 & & & \\
\hline \multirow{3}{*}{\multicolumn{2}{|c|}{ Patient loyalty (PL) }} & PL1 & 0.931 & \multirow[t]{3}{*}{0.923} & \multirow[t]{3}{*}{0.951} & 0.867 \\
\hline & & PL2 & 0.956 & & & \\
\hline & & PL3 & 0.905 & & & \\
\hline Patient participation (PP) & & PP2 & 0.643 & 0.775 & 0.846 & 0.525 \\
\hline & & PP5 & 0.716 & & & \\
\hline & & PP6 & 0.791 & & & \\
\hline & & PP7 & 0.688 & & & \\
\hline & & PP8 & 0.774 & & & \\
\hline Patient trust in doctor (PT) & & PT1 & 0.751 & 0.832 & 0.889 & 0.667 \\
\hline & & PT2 & 0.860 & & & \\
\hline & & PT3 & 0.809 & & & \\
\hline & & PT4 & 0.841 & & & \\
\hline Relationship commitment (RC) & & $R C 1$ & 0.871 & 0.869 & 0.906 & 0.659 \\
\hline & & $\mathrm{RC} 2$ & 0.860 & & & \\
\hline & & $\mathrm{RC} 3$ & 0.808 & & & \\
\hline & & $\mathrm{RC} 4$ & 0.815 & & & \\
\hline & & $R C 5$ & 0.695 & & & \\
\hline
\end{tabular}

Note: RC1 and RC5 were deleted to achieve satisfactory level of discriminant validity between relationship commitment (RC) and patient loyalty (PL). Second-order construct = patient perceived control. Items PP1, PP3, PP4 were removed due to low loadings.

Abbreviations: AVE, average variance extracted, $C R$, composite reliability. 
TAB LE 3 Discriminant validity assessment using the Heterotrait-Monotrait (HTMT) criterion

\begin{tabular}{|c|c|c|c|c|c|c|c|c|}
\hline \multicolumn{2}{|c|}{ Constructs } & DS & PC & PE & PL & PP & PT & $\mathrm{RC}$ \\
\hline 2 & PC & 0.604 & & & & & & \\
\hline \multirow[t]{2}{*}{3} & PE & 0.883 & 0.577 & & & & & \\
\hline & & {$[0.82,0.93]$} & {$[0.43,0.71]$} & & & & & \\
\hline 4 & & {$[0.70,0.84]$} & {$[0.46,0.64]$} & {$[0.64,0.82]$} & & & & \\
\hline \multirow[t]{2}{*}{5} & PP & 0.460 & 0.804 & 0.405 & 0.446 & & & \\
\hline & & {$[0.30,0.65]$} & {$[0.73,0.88]$} & {$[0.26,0.56]$} & {$[0.31,0.60]$} & & & \\
\hline 6 & PT & 0.878 & 0.571 & 0.837 & 0.875 & 0.430 & & \\
\hline
\end{tabular}

Note: Items RC1 and RC5 were deleted to achieve satisfactory level of discriminant validity between RC and PL. Numbers in brackets represent the 95\% Bias-corrected and accelerated (BCa) confidence intervals obtained from bootstrapping procedure with 5,000 resamples.

Abbreviations: DS, doctor support; PC, patient perceived control; PE, patient education; PL, patient loyalty; PP, patient participation; PT, patient trust in doctor; RC, relationship commitment.

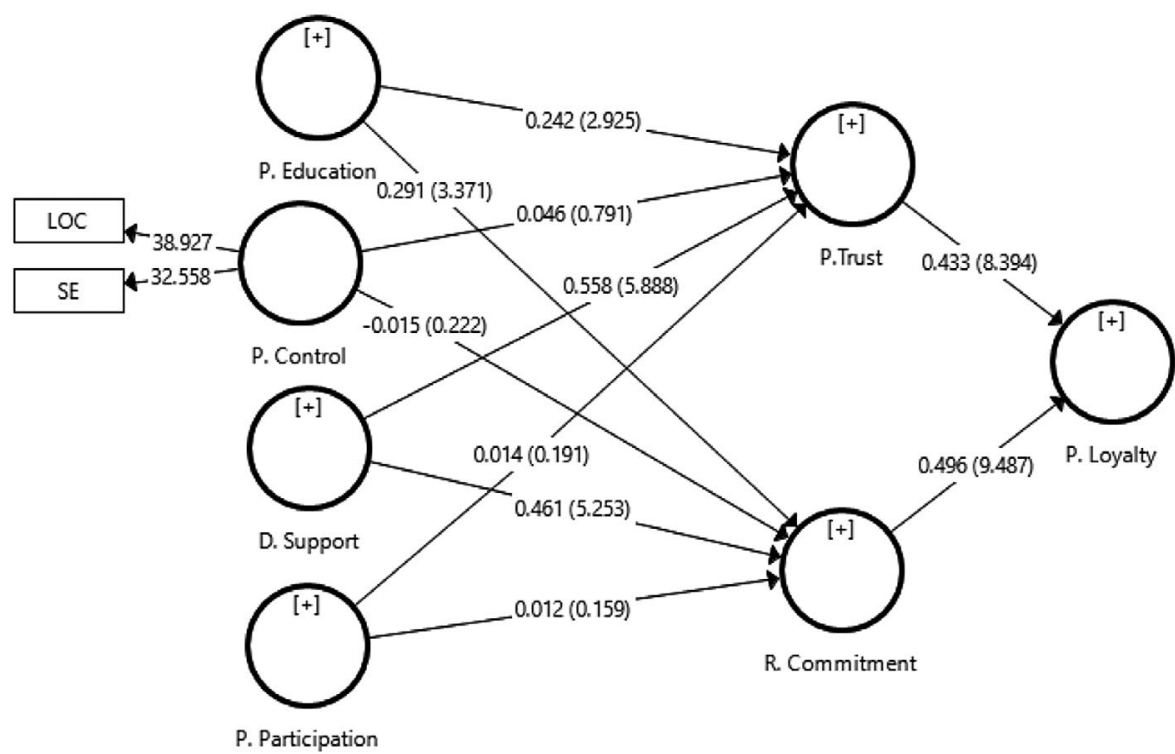

FIGURE 2 Structural model analysis using SmartPLS. Using latent variable scores, Patient Control was measured as a second-order reflective construct with locus of control (LOC) and self-efficacy (SE) as subdimensions, while other variables were unidimensional reflective measures. The path values show "standardised path coefficient (critical $t$-value)"

TABLE 4 Assessment of common method variance

\begin{tabular}{|c|c|c|c|}
\hline Endogenous constructs & $\begin{array}{l}R^{2} \\
\text { (Baseline } \\
\text { model) }\end{array}$ & $\begin{array}{l}R^{2} \text { (with } \\
\text { MLMV) }\end{array}$ & Difference \\
\hline Patient trust in doctor & 0.634 & 0.637 & 0.003 \\
\hline Relationship commitment & 0.509 & 0.511 & 0.002 \\
\hline Patient loyalty & 0.723 & 0.725 & 0.002 \\
\hline
\end{tabular}

theoretical model and contains hypotheses formulated based on theoretical backgrounds (Hair et al., 2014). In this study, the structural model was assessed by observing the effects of patient education, patient perceived control, doctor support and patient participation on patient trust in doctor and relationship commitment, and finally on patient loyalty. To determine whether collinearity amongst the antecedent variables exists, the variance inflation factor (VIF) was obtained. All VIF values in Table 5 are below the threshold of 5.0 
TAB LE 5 Results of hypothesis testing with PLS-SEM $(N=234)$

\begin{tabular}{|c|c|c|c|c|c|c|c|c|c|}
\hline \multicolumn{2}{|c|}{ Hypotheses } & \multirow{2}{*}{$\begin{array}{l}\text { Std. } \\
\text { beta } \\
{ }^{* *} 0.242\end{array}$} & \multirow{2}{*}{$\begin{array}{l}\text { SE } \\
0.082\end{array}$} & \multirow{2}{*}{$\begin{array}{l}\begin{array}{l}\text { Confidence } \\
\text { interval (BC) }\end{array} \\
{[0.098,0.372]}\end{array}$} & \multirow{2}{*}{$\begin{array}{l}\text { Decision } \\
\text { Supported }\end{array}$} & \multirow{2}{*}{$\begin{array}{l}\text { VIF } \\
2.867\end{array}$} & \multirow{2}{*}{$\begin{array}{l}R^{2} \\
0.635\end{array}$} & \multirow{2}{*}{$\begin{array}{l}f^{2} \\
0.056\end{array}$} & \multirow{2}{*}{$\begin{array}{l}Q^{2} \\
0.404\end{array}$} \\
\hline $\mathrm{H} 1 \mathrm{a}$ & $\mathrm{PE} \rightarrow \mathrm{PT}$ & & & & & & & & \\
\hline H3а & $\mathrm{DS} \rightarrow \mathrm{PT}$ & ${ }^{* * *} 0.558$ & 0.095 & {$[0.413,0.731]$} & Supported & 3.086 & & 0.276 & \\
\hline $\mathrm{H} 4 \mathrm{a}$ & $\mathrm{PP} \rightarrow \mathrm{PT}$ & 0.014 & 0.075 & {$[-0.122,0.122]$} & Not supported & 1.687 & & 0.000 & \\
\hline $\mathrm{H} 2 \mathrm{~b}$ & $\mathrm{PC} \rightarrow \mathrm{RC}$ & -0.015 & 0.066 & {$[-0.121,0.096]$} & Not supported & 1.927 & & 0.000 & \\
\hline $\mathrm{H} 3 \mathrm{~b}$ & $\mathrm{DS} \rightarrow \mathrm{RC}$ & ${ }^{* * *} 0.461$ & 0.088 & {$[0.312,0.599]$} & Supported & 3.086 & & 0.140 & \\
\hline $\mathrm{H} 4 \mathrm{~b}$ & $\mathrm{PP} \rightarrow \mathrm{RC}$ & 0.012 & 0.073 & {$[-0.118,0.119]$} & Not supported & 1.687 & & 0.000 & \\
\hline $\mathrm{H} 5$ & $\mathrm{PT} \rightarrow \mathrm{PL}$ & ${ }^{* * *} 0.433$ & 0.051 & {$[0.351,0.517]$} & Supported & 1.833 & 0.723 & 0.370 & 0.615 \\
\hline H6 & $\mathrm{RC} \rightarrow \mathrm{PL}$ & ${ }^{* * *} 0.496$ & 0.052 & {$[0.411,0.580]$} & Supported & 1.833 & & 0.484 & \\
\hline
\end{tabular}

Note: Significance at critical $t$-value Standard error; BC 95\% bias-corrected.

Abbreviations: DS, doctor support; PC, patient perceived control; PL, patient loyalty; PP, patient participation; PR, patient education; PT, patient trust in doctor; RC, relationship commitment.

${ }^{*} 1.65(p<.05) ;{ }^{* *} 2.33(p<.01) ;{ }^{* * *} 3.09(p<.001)$ [One-tailed].

(Hair, Hult, et al., 2017), thus ruling out multicollinearity. To evaluate the structural model and examine the 10 hypotheses in this study, bootstrapping was conducted with 5,000 resamples. Referring to the path coefficients in Table 5, six hypotheses exhibited $t$-values of at least $>2.33$, significant at $p<.01$ level (Hair, Hult, et al., 2017). Two of the patient empowerment dimensions, that is, patient education and doctor support, were found to have a significant positive effect on both patient trust in doctor and relationship commitment; thus, $\mathrm{H} 1 \mathrm{a}, \mathrm{H} 1 \mathrm{~b}, \mathrm{H} 3 \mathrm{a}$, and $\mathrm{H} 3 \mathrm{~b}$ were supported $(p<.01)$. However, the results were not supportive for the two remaining dimensions. Patient perceived control and patient participation constructs showed no significant impact on patient trust in doctor or relationship commitment; hence, $\mathrm{H} 2 \mathrm{a}, \mathrm{H} 2 \mathrm{~b}, \mathrm{H} 4 \mathrm{a}$, and $\mathrm{H} 4 \mathrm{~b}$ were not supported. Finally, the effects of patient trust in doctor and relationship commitment on patient loyalty were found to be both significant and positive ( $p<.01$ ), supporting H5 and H6. According to Cohen (1988), the effect size $f^{2}$ to $R^{2}$ is benchmarked as $0.02,0.15$ and 0.35 for small, medium and substantial effect sizes, respectively. As indicated in Table 5, doctor support $\left(f^{2}=0.28\right)$ had a stronger medium effect size compared to a small effect size of patient education $\left(f^{2}=0.06\right)$ for patient trust in doctor. Additionally, doctor support $\left(f^{2}=0.14\right)$ had a marginal medium effect size compared to a small effect size of patient education $\left(f^{2}=0.06\right.$ ) for relationship commitment. Relationship commitment, in turn, had a substantially larger effect size $\left(f^{2}=0.48\right)$ than patient trust in doctor $\left(f^{2}=0.37\right)$ in explaining patient loyalty. These results suggest that doctor support, followed by patient education, is the most important components in building patient trust and commitment. Furthermore, relationship commitment and trust are both essential predictors of creating patient loyalty in a healthcare setting.

In a structural model, $R^{2}$ refers to the amount of variance explained by the predictors, which are categorised as $0.19,0.33$ and 0.67 for weak, moderate and substantial, respectively (Chin, 1998). The results indicated that the study model had a moderate to substantial level of explanation ability. Precisely, the highest amount of variance (i.e., 73.3\%) of patient loyalty was explained by relationship commitment and trust. Finally, to assess the predictive relevance of the endogenous variables, $Q^{2}$ values were observed. The $Q^{2}$ values for patient trust in doctor (0.404), relationship commitment (0.369) and patient loyalty (0.615) were above zero, providing support for the model's medium-to-large predictive relevance (Hair et al., 2019).

\section{5 | DISCUSSIONS AND IMPLICATIONS}

\section{1 | Patient trust in doctor, relationship commitment and patient loyalty}

Oliver (1999, p. 34) defines loyalty as 'a deeply held commitment to rebuy or patronise a preferred product or service consistently in the future, despite situational influences and marketing efforts having the potential to cause switching behaviour'. However, such definitions have been critiqued for their limitations in differentiating loyalty from commitment, which this and other studies recognise as distinct concepts. Although Li and Petrick (2010) put forward that commitment and attitudinal loyalty are similar measures, these two constructs could be distinguished based on the theoretical definition and measurement of loyalty (i.e., behavioural and attitudinal loyalty) adopted by the researcher. For their part, Moreira and Silva (2015) also stated that commitment and loyalty differ and serve as two distinct constructs. Our findings not only discriminate between these two variables as separate measures but also identified a central role of relationship commitment in driving patient loyalty. These results are also aligned with previous studies such as Gremler et al. (2020) and Verhoef (2003).

Between the two antecedents of patient loyalty (i.e., relationship commitment and trust), this study substantiates that relationship 
commitment is a stronger predictor than patient trust in building a patient's loyalty to a doctor. Past studies have found that both commitment and trust foster loyalty. Huang et al. (2019) postulated that commitment exerts a stronger influence than trust in building patient loyalty, whereas Čater and Čater (2010) stated that commitment creates an optimistic intention to sustain and reinforce a relationship; as such, customer loyalty is positively influenced by commitment. Other studies have also shown customer commitment to play a crucial role in the formation of customer loyalty (Fullerton, 2009). More specifically, studies in healthcare marketing have emphasised the prominent role of relationship commitment and trust in the loyalty of a patient towards a doctor or a hospital (Kim et al., 2008; Torres et al., 2009).

\section{2 | Multidimensionality of patient perceived control}

Despite removing half of the patient perceived control items due to low item loadings and poor AVE and CR, we conducted further testing to rule out multidimensionality. In contrast to our initial construct, which was adapted and built on Ouschan et al.'s (2006) proposed dimension of patient perceived control, our EFA test uncovered two separate components, Component A (locus of control): LOC1 (0.741), LOC2 (0.801), LOC3 (0.677), LOC7 (0.611) and Component B (self-efficacy): SE1 (0.807), SE2 (0.690), SE3 (0.717), SE4 (0.491). This result suggests that patient perceived control is a second-order construct, while self-efficacy and locus of control constitute the first-order constructs (Claassens et al., 2014; Kozela et al., 2017; O'Hea et al., 2009). For chronic illnesses, these two psychological factors play a crucial role in disease management (Cross et al., 2006). The idea of self-efficacy was first introduced by Bandura (1978) in reference to one's belief in their own ability to pass through the necessary steps to reach a desired outcome. Patients who possess a high sense of self-efficacy are usually capable of dealing with life stressors (Salehi et al., 2016) and will have more positive health outcomes than disempowered patients-that is, patients with a low sense of self-efficacy (Akeel \& Mundy, 2015). Another perceived control subdimension that often goes together with self-efficacy is locus of control (Gabay, 2015; O'Hea et al., 2009). This concept was initially popularised by Rotter's (1966) theory of social learning and has since been extended by Wallston et al. (1987), who studied the multidimensional aspect of perceived control. Internal locus of control refers to the extent to which people believe they are personally responsible for their own health. Individuals who have a high internal locus of control, and therefore feel that they have a grip on their own health, may be less inclined to perform certain routines or take certain precautions that are crucial for maintaining good health (Roddenberry \& Renk, 2010). A study by Cross et al. (2006) and Bohanny et al. (2013) concerning arthritis-related diseases and type 2 diabetes, respectively, reported better health status with higher self-efficacy and internal locus of control. Thus, both first-order constructs (i.e., self-efficacy and locus of control) are equally important, and patients are likely to feel they are in control of their health, taking necessary precautionary measures to maintain good health.

\section{3 | Theoretical and managerial implications}

This study offers several interesting theoretical contributions. Most importantly, the study identifies physician-based attributes (i.e., doctor support and patient education) and patient-based attributes (i.e., patient's perceived control and patient participation) as patient empowerment components which play essential roles in cultivating profitable patient-doctor relationship and building patient loyalty. Our findings on patient education and doctor support are in line with past studies (Berry et al., 2008; Birkhäuer et al., 2017; Ouschan et al., 2006; Suh et al., 2015; Yin \& Yang, 2009). Both patient education and doctor support played a significant role in enhancing the patient-doctor bond. Results showed that patient empowerment through patient education and doctor support had a positive influence on the level of patient trust and commitment towards their doctor, eventually strengthening loyalty in the relationship. More precisely, the doctor support dimension has emerged as the strongest predictor of patient trust in doctor and relationship commitment-even stronger than patient education. This research attests that a positive significant effect of patient education on patient-doctor bond extends the patient empowerment theory by explaining a meaningful constituent of patient empowerment. Besides, patient trust and relationship commitment have also appeared as essential factors in fostering patients' loyalty towards their doctors, which further supports the outcome of patient empowerment theory.

The result from our research presents several avenues that can be adopted by service managers as well as by doctors in order to cultivate patient loyalty. Senić and Marinković (2013) stated that healthcare organisations must strive to achieve long-term patient relationships to build patient loyalty. Our research indicates that doctor support and patient education are the most crucial areas of focus when cultivating patient loyalty through patient-doctor relationships. In this vein, it has become indispensable for healthcare providers to offer emotional support by allowing patients to be open, showing concern for their wellbeing and offering encouragement when confronting illness. Doctors should also provide educational support to keep patients informed and explain the advantages and disadvantages of treatment options. This way, patients can better understand and make more informed choices about their own health management. When educating the patient is done right, patients will forge emotional attachments to their preferred doctor, subsequently increasing word-of-mouth recommendations, repurchasing and readiness to pay more, ultimately leading to profitable long-term relationships (Evanschitzky et al., 2012).

Patient participation and patient perceived control were not found to be significant factors contributing to patients' trust in doctors and relationship commitment. However, much to our surpriseand contrary to our prediction-not only is patient perceived control 
insignificant, it also indicated an opposite sign change: patient perceived control indicated a negative relationship towards relationship commitment only. This result may be attributable to the one-way-or 'paternalistic'-consultation style with very limited patient input or participation that is seen as common in Southeast Asia (Claramita et al., 2013). This appears to be related to the characteristics of Asian culture as being socially distant with traditional or close-minded communication style, particularly for those who stick to culturally determined behaviours. Moreover, due to the technical knowledge and expertise associated with diagnoses and treatments of healthrelated diseases, the general public may lack understanding about the medical service and treatments they are receiving (Schmidlen et al., 2016). Hence, most patients may not be able to adequately manage their acute illnesses by themselves. Roter (2000) also explained that patients habitually do not participate at levels that are crucial for positive outcomes; only one third of patients responsibly take on participative roles, and many encounters are verbally dominated by doctors. Gabay (2015) reported that patients' trust in doctors is heightened by the patients' perceived control when participatory communication exists in a patient-doctor relationship. Sometimes patients develop mistrust of doctors following negative experiences and previous disappointments with the healthcare system (Hardavella et al., 2017). Having said that, some patients with a higher level of self-control over their health management might not follow doctor's suggestions only. Such patients tend to educate themselves by consulting friends and family who have been suffering from similar diseases (Stenberg et al., 2019). In the Asian region, for example, some patients also refer to social media platforms such as Facebook and YouTube for remedies to their illness, despite visiting doctors (Nguyen, 2020). Hence, in a one-way-or 'paternalistic'relationship culture, a higher level of patient perceived control leads to a lower level of patient trust and relationship commitment toward their doctors.

For our study, we did not examine the respondents by classifying them based on specific chronic illnesses such as diabetes, heart diseases, lung diseases or cancer which require a patient's active control over health management. This could possibly be the contributing factor for the insignificant relationship concerning the patient-based attributes of patient participation and patient perceived control on patient trust in doctor and relationship commitment. Referring to Table 1, the top three areas of consultation from the data collected were ear, nose and throat (ENT), orthopaedic and gastroenterology. These specialties usually draw in many patients with acute illnesses such as mild sinusitis, gastritis and minor joint injuries, which do not require significant control from patients. Stenberg et al. (2019) assert that responsibility for symptom management increasingly shifts from doctors to patients themselves with chronic medical conditions. Hence, patient participation and patient perceived control are critical in shaping the outcome of healthcare consultation. Our results indicate that more than ever, there is a need to encourage patients to empower themselves. They should also be encouraged to become co-partners with their doctors for managing their illnesses and sharing decisions about the best remedy or outcome. Also, health providers need to view the patient's role as being as important as theirs (Bitner et al., 1997) and therefore design a setting that would drive the best possible health outcomes.

\section{6 | DIRECTIONS FOR FUTURE RESEARCH}

Despite the theoretical contributions and managerial implications, this study is not without limitations, which in turn provides opportunities for future research. First, the findings may be limited in terms of generalisation since the conclusion was drawn from a single study site-the sample was obtained from only one private healthcare facility. Exploration by surveying patients from several private hospitals should be considered. Responses from patients might also differ if the study were conducted in a government hospital. Academics should contemplate this point because the levels of service delivery and quality of healthcare differ between these two sectors. Another area that can be investigated is the narrowing down of patient selection to include only those who require high-involvement, long-term critical care. For example, only patients with cardiovascular disease, cancer, diabetes or chronic sports injury would be selected, as opposed to randomly picking patients across the range of specialties. Such patients may be more likely to have developed a deeper bond and have a more concrete perception of their doctors. Therefore, future research should examine our proposed theoretical model by adding moderating variables, such as the nature of medical care (i.e., high-involvement, long-term critical care vs. low-involvement, shortterm critical care) and nature of hospitals (i.e., private vs. public). A moderating variable can significantly influence the relationships amongst variables in the model by either strengthening or weakening them, which can offer potential strategic directions for providers. Additionally, scholars could also look into the fact that several factors could influence a patient's character, which can dictate their level of participation, perceived control and receptiveness to support (Gallan et al., 2013). The Big Five personality traits of agreeableness, openness, conscientiousness, extraversion and neuroticism could play a role here. Patients with different personality traits may participate in the patient-doctor relationship in very distinct ways. By doing this, healthcare providers can have a better way of understanding and dealing with patients with different characters and personality. Thus, the findings of this study may not be broadly applicable to all patients; further research is certainly needed along the avenues described above.

\section{7 | CONCLUSION}

With the emergence of intense competition in the industry, healthcare providers need to play a more significant role than before in promoting collaborative relationships between patients and doctors. This research advocates that patient empowerment leads to satisfactory outcomes, which further fosters patients' loyalty towards their doctors. Hence, empowering patients would be necessary to 
ensure favourable healthcare service outcomes, especially in managing chronic illnesses. Patients' mere presence during healthcare consultation is often insufficient to maximise the satisfactory outcomes of clinical results. Most medical conditions require patients' active participation in the form of empowerment in order to result in a successful collaborative patient-doctor relationship. Our findings also substantiate that allowing patients to learn about their illness and potential treatments (i.e., patient education) while ensuring doctor support concerning health management, advice and medication are essential aspects of nurturing the patient-doctor relationship. This research also reveals that empowering patients strengthens their trust towards doctors and relationship commitment, which is central in building loyalty. Therefore, healthcare providers should promote a better service environment where doctors clarify the causes of illness, medication details and management of health during consultations and treatments. Such a service setting would motivate the patient to engage actively in managing their illness, increase trust and commitment towards their doctors, which in turn drive patient loyalty.

\section{ACKNOWLEDGEMENTS}

We would like to thank the management of Springsteen Medical Centre, Malaysia (a fictitious name for anonymity purposes) for allowing us to conduct our survey in their establishment.

\section{CONFLICT OF INTEREST}

We declare no conflicts of interest concerning this article.

\section{DATA AVAILABILITY STATEMENT}

The data that support the findings of this study are available on request from the corresponding author. The data are not publicly available due to privacy or ethical restrictions.

\section{ORCID}

Amrul Asraf Mohd-Any (iD https://orcid.org/0000-0002-9112-2905 Moniruzzaman Sarker (iD https://orcid.org/0000-0003-3595-5838

\section{REFERENCES}

Afthanorhan, A., Awang, Z., \& Fazella, S. (2017). Developing the patients loyalty model for medical tourism industry: The case of Malaysia. International Journal of Society Systems Science, 9(2), 139-164. https:// doi.org/10.1504/IJSSS.2017.085710

Akeel, A. U., \& Mundy, D. (2015). Comparison of patient empowerment frameworks. In Proceedings-2015 IEEE International Conference on Healthcare Informatics, ICHI 2015, Institute of Electrical and Electronics Engineers Inc, pp. 282-286.

Alexander, J., Hearld, L., \& Mittler, J. N. (2014). Patient-physician role relationships and patient activation: The moderating effects of race and ethnicity. Medical Care Research and Review, 71(5), 472-495. https://doi.org/10.1177/1077558714541967

Alicia, S. M. T., Chee, S., Rajaram, R., Kowitlawakul, Y., \& Liaw, S. Y. (2020) Missed nursing care in patient education: A qualitative study of different levels of nurses' perspectives. Journal of Nursing Management, 28(8), 1960-1967. https://doi.org/10.1111/jonm.12983

Aliman, N. K., \& Mohamad, W. N. (2016). Linking service quality, patients satisfaction and behavioral intentions: An investigation on private healthcare in Malaysia. Procedia-Social and Behavioral Sciences, 224 141-148. https://doi.org/10.1016/j.sbspro.2016.05.419

Aljumaha, A., Nuseirb, M. T., \& Islamc, A. (2020). Impacts of service quality, satisfaction and trust on the loyalty of foreign patients in Malaysian medical tourism. International Journal of Innovation, Creativity and Change, 11(2), 451-467.

Allender, W. J., \& Richards, T. J. (2012). Brand loyalty and Price promotion strategies: An empirical analysis. Journal of Retailing, 88(3), 323342. https://doi.org/10.1016/j.jretai.2012.01.001

Astuti, H. J., \& Nagase, K. (2014). Patient loyalty to health care organizations: Strengthening and weakening (satisfaction and provider switching). Journal of Medical Marketing, 14(4), 191-200. https://doi. org/10.1177/1745790415578311

Auh, S., Bell, S. J., McLeod, C. S., \& Shih, E. (2007). Co-production and customer loyalty in financial services. Journal of Retailing, 83(3), 359370. https://doi.org/10.1016/j.jretai.2007.03.001

Auh, S., Menguc, B., Katsikeas, C. S., \& Jung, Y. S. (2019). When does customer participation matter? An empirical investigation of the role of customer empowerment in the customer participation-performance link. Journal of Marketing Research, 56(6), 1012-1033. https://doi. org/10.1177/0022243719866408

Aujoulat, I., d'Hoore, W., \& Deccache, A. (2007). Patient empowerment in theory and practice: Polysemy or cacophony? Patient Education and Counseling, 66(1), 13-20. https://doi.org/10.1016/j.pec.2006.09.008

Bal, P. M., Kooij, D. R., \& De Jong, S. B. (2013). How do developmental and accommodative HRM enhance employee engagement and commitment? The role of psychological contract and SOC strategies. Journal of Management Studies, 50(4), 545-572.

Bandura, A. (1978). Self-efficacy: Toward a unifying theory of behavioral change. Advances in Behaviour Research and Therapy, 1(4), 139-161. https://doi.org/10.1016/0146-6402(78)90002-4

Bell, S. J., Auh, S., \& Eisingerich, A. B. (2017). Unraveling the customer education paradox: When, and how, should firms educate their customers? Journal of Service Research, 20(3), 306-321. https://doi. org/10.1177/1094670517691847

Bell, S. J., \& Eisingerich, A. B. (2007). The paradox of customer education: Customer expertise and loyalty in the financial services industry. European Journal of Marketing, 41(5), 466-486. https://doi. org/10.1108/03090560710737561

Ben Ayed, M., \& El Aoud, N. (2017). The patient empowerment: A promising concept in healthcare marketing. International Journal of Healthcare Management, 10(1), 42-48. https://doi. org/10.1080/20479700.2016.1268326

Berry, L. L., Parish, J. T., Janakiraman, R., Russell, L. O., Couchman, G. R., Rayburn, W. L., \& Grisel, J. (2008). Patients' commitment to their physician and why it matters. Annals of Family Medicine, 6(1), 6-13.

Birkhäuer, J., Gaab, J., Kossowsky, J., Hasler, S., Krummenacher, P., Werner, C., \& Gerger, H. (2017). Trust in the health care professional and health outcome: A meta-analysis. PLoS One, 12(2), 1-13. https:// doi.org/10.1371/journal.pone.0170988

Bitner, J. M., Faranda, W. T., Hubbert, A. R., \& Zeithaml, V. A. (1997). Customer contributions and roles in service delivery. International Journal of Service Industry Management, 8(3), 193-205. https://doi. org/10.1108/09564239710185398

Bohanny, W., Wu, S. F., Liu, C. Y., Yeh, S. H., Tsay, S. L., \& Wang, T. J. (2013). Health literacy, self-efficacy, and self-care behaviors in patients with type 2 diabetes mellitus. Journal of the American Association of Nurse Practitioners, 25(9), 495-502. https://doi. org/10.1111/1745-7599.12017

Bonsignore, C., Brolis, E., Alexandra, I., Karusinova, V., Mitkova, Z., Raps, F., Renman, V., \& Fedotova, N. R. (2015). Patient Empowerment and Centredness. In European Health Parliament. 7 Recommendations on Healthcare in Europe.

Brennan, C., \& Coppack, M. (2008). Consumer empowerment: Global context, UK strategies and vulnerable consumers. International 
Journal of Consumer Studies, 32(4), 306-313. https://doi. org/10.1111/j.1470-6431.2007.00640.x

Bulsara, C. E., \& Styles, I. (2013). Development of a cancer related patient empowerment scale using the polytomous Rasch measurement mode. Cancer and Clinical Oncology, 2(1), 87-102.

Cain, M. K., Zhang, Z., \& Yuan, K. H. (2017). Univariate and multivariate skewness and kurtosis for measuring nonnormality: Prevalence, influence and estimation. Behavior Research Methods, 49(5), 17161735. https://doi.org/10.3758/s13428-016-0814-1

Camacho, N., De Jong, M., \& Stremersch, S. (2014). The effect of customer empowerment on adherence to expert advice. International Journal of Research in Marketing, 31(3), 293-308. https://doi.org/10.1016/j.jjres mar.2014.03.004

Čater, T., \& Čater, B. (2010). Product and relationship quality influence on customer commitment and loyalty in B2B manufacturing relationships. Industrial Marketing Management, 39(8), 1321-1333. https:// doi.org/10.1016/j.indmarman.2010.02.006

Chan, K. W., Yim, C. K. B., \& Lam, S. S. K. (2010). Is customer participation in value creation a double-edged sword? Evidence from professional financial services across cultures. Journal of Marketing, 74(3), 48-64. https://doi.org/10.1509/jmkg.74.3.048

Chang, C., Tseng, T. H., \& Woodside, A. G. (2013). Configural algorithms of patient satisfaction, participation in diagnostics, and treatment decisions' influences on hospital loyalty. Journal of Services Marketing, 27(2), 91-103. https://doi.org/10.1108/08876 041311309225

Chatzimarkakis, J. (2010). Why patients should be more empowered: A European perspective on lessons learned in the management of diabetes. Journal of Diabetes Science and Technology, 4(6), 1570-1573. https://doi.org/10.1177/193229681000400634

Cheah, J.-H., Waller, D., Thaichon, P., Ting, H., \& Lim, X.-J. (2020). Price image and the sugrophobia effect on luxury retail purchase intention. Journal of Retailing and Consumer Services, 57, 102188.

Chen, J., Mullins, C. D., Novak, P., \& Thomas, S. B. (2016). Personalized strategies to activate and empower patients in health care and reduce health disparities. Health Education and Behavior, 43(1), 25-34. https://doi.org/10.1177/1090198115579415

Chin, W. W. (1998). The partial least squares approach to structural equation modeling. In G. A. Marcoulides (Ed.), Modern methods for business research. Lawrence Erlbaum.

Chin, W. W., Thatcher, J. B., Wright, R. T., \& Steel, D. (2013). Controlling for common method variance in PLS analysis: The measured latent marker variable approach. Springer Proceedings in Mathematics and Statistics, 56, 231-239.

Chiu, C. M., Hsu, M. H., Lai, H., \& Chang, C. M. (2012). Re-examining the influence of trust on online repeat purchase intention: The moderating role of habit and its antecedents. Decision Support Systems, 53(4), 835-845. https://doi.org/10.1016/j.dss.2012.05.021

Christens, B. D., Peterson, N. A., \& Speer, P. W. (2011). Community participation and psychological empowerment: Testing reciprocal causality using a cross-lagged panel design and latent constructs. Health Education and Behavior, 38(4), 339-347. https://doi. org/10.1177/1090198110372880

Chuah, S.-H.-W., Rauschnabel, P. A., Tseng, M.-L., \& Ramayah, T. (2018). Reducing temptation to switch mobile data service providers over time: The role of dedication vs constraint. Industrial Management \& Data Systems, 118(8), 1597-1628. https://doi.org/10.1108/ IMDS-07-2017-0326

Claassens, L., Widdershoven, G. A., Van Rhijn, S. C., Van Nes, F., Broese van Groenou, M. I., Deeg, D. J. H., \& Huisman, M. (2014). Perceived control in health care: A conceptual model based on experiences of frail older adults. Journal of Aging Studies, 31, 159-170. https://doi. org/10.1016/j.jaging.2014.09.008

Claramita, M., Nugraheni, M. D. F., van Dalen, J., \& van der Vleuten, C. (2013). Doctor-patient communication in Southeast Asia: A different culture? Advances in Health Sciences Education, 18(1), 15-31. https:// doi.org/10.1007/s10459-012-9352-5

Clark, P. G. (2014). Narrative in interprofessional education and practice: Implications for professional identity, provider-patient communication and teamwork. Journal of Interprofessional Care, 28(1), 34-39. https://doi.org/10.3109/13561820.2013.853652

Cohen, J. (1988). Statistical power analysis for the behavioural science. Lawrence Erlbaum Associates.

Cox, H., Ski, C. F., Wood, R., \& Sheahan, M. (2003). Endometriosis, an unknown entity: The consumer's perspective. International Journal of Consumer Studies, 27(3), 200-209. https://doi. org/10.1046/j.1470-6431.2003.00302.x

Cross, M. J., March, L. M., Lapsley, H. M., Byrne, E., \& Brooks, P. M. (2006). Patient self-efficacy and health locus of control: Relationships with health status and arthritis-related expenditure. Rheumatology, 45(1), 92-96. https://doi.org/10.1093/rheumatology/kei114

Dong, B., \& Sivakumar, K. (2017). Customer participation in services: Domain, scope, and boundaries. Journal of the Academy of Marketing Science, 45(6), 944-965. https://doi.org/10.1007/s11747-017-0524-y

Dos Santos, C. P., \& Basso, K. (2012). Do ongoing relationships buffer the effects of service recovery on customers' trust and loyalty? International Journal of Bank Marketing, 30(3), 168-192. https://doi. org/10.1108/02652321211222540

Eisingerich, A. B., Auh, S., \& Merlo, O. (2014). Acta non verba? The role of customer participation and word of mouth in the relationship between service firms' customer satisfaction and sales performance. Journal of Service Research, 17(1), 40-53. https://doi. org/10.1177/1094670513490836

Eisingerich, A. B., \& Bell, S. J. (2006). Relationship marketing in the financial services industry: The importance of customer education, participation and problem management for customer loyalty. Journal of Financial Services Marketing, 10(4), 86-97. https://doi.org/10.1057/ palgrave.fsm. 4760022

Eisingerich, A. B., \& Bell, S. J. (2008). Perceived service quality and customer trust: Does enhancing customers' service knowledge matter? Journal of Service Research, 10(3), 256-268. https://doi. org/10.1177/1094670507310769

European Patients' Forum. (2015). EPF background brief: Patient empowerment. A Strong Patient's Voice to Drive Better Health in Europe, p. 12. http://www.eu-patient.eu/globalassets/campaign-patientempowerment/briefing_paperpatient-empowerment_final_exter nal.pdf\%0Awww.eu-patient.eu

Evanschitzky, H., Ramaseshan, B., Woisetschläger, D. M., Richelsen, V., Blut, M., \& Backhaus, C. (2012). Consequences of customer loyalty to the loyalty program and to the company. Journal of the Academy of Marketing Science, 40(5), 625-638. https://doi.org/10.1007/s1174 7-011-0272-3

Faul, F., Erdfelder, E., Lang, A.-G., \& Buchner, A. (2009). Statistical power analyses using $\mathrm{G}^{*}$ Power 3.1: Test for correlation and regression analysis. Behavior Research Methods, 41(4), 1149-1160.

Feste, C., \& Anderson, R. M. (1995). Empowerment: From philosophy to practice. Patient Education and Counseling, 26(1), 139-144. https:// doi.org/10.1016/0738-3991(95)00730-N

Fodness, D., Pitegoff, B. E., \& Sautter, E. T. (1993). From customer to competitor: Consumer cooption in the service sector. Journal of Services Marketing, 7(3), 18-25. https://doi.org/10.1108/08876 049310044529

Fornell, C., \& Larcker, D. F. (1981). Structural equation models with unobservable variables and measurement error: Algebra and statistics. Journal of Marketing Research, 18(3), 382-388. https://doi. org/10.1177/002224378101800313

Franke, G., \& Sarstedt, M. (2019). Heuristics versus statistics in discriminant validity testing: A comparison of four procedures. Internet Research, 29(3), 430-447. https://doi.org/10.1108/ IntR-12-2017-0515 
Fuller, C. M., Simmering, M. J., Atinc, G., Atinc, Y., \& Babin, B. J. (2016). Common methods variance detection in business research. Journal of Business Research, 69(8), 3192-3198. https://doi.org/10.1016/j.jbusr es.2015.12.008

Fullerton, G. (2009). When does commitment lead to loyalty? Journal of Service Research, 5(4), 333-344. https://doi.org/10.1177/10946 70503005004005

Gabay, G. (2015). Perceived control over health, communication and patient-physician trust. Patient Education and Counseling, 98(12), 1550-1557. https://doi.org/10.1016/j.pec.2015.06.019

Gabay, G. (2016). Does trust of patients in their physician predict loyalty to the health care insurer? The Israeli case study. Health Marketing Quarterly, 33(2), 149-162. https://doi.org/10.1080/07359 683.2016.1166854

Gallan, A. S., Jarvis, C. B., Brown, S. W., \& Bitner, M. J. (2013). Customer positivity and participation in services: An empirical test in a health care context. Journal of the Academy of Marketing Science, 41(3), 338356. https://doi.org/10.1007/s11747-012-0307-4

Gensichen, J., Von Korff, M., Rutter, C. M., Seelig, M. D., Ludman, E. J., Lin, E. H. B., Ciechanowski, P., Young, B. A., Wagner, E. H., \& Katon, W. J. (2009). Physician support for diabetes patients and clinical outcomes. BMC Public Health, 9, 1-8. https://doi.org/10.1186/1471-2458-9-367

Gibson, C. H. (1991). A concept analysis of empowerment. Journal of Advanced Nursing, 16(1991), 354-361. https://doi.org/10.1111/ j.1365-2648.1991.tb01660.x

Gould, W. R. (2017). The real reason that going to the doctor gives you anxiety. NBC News Wellness. https://www.nbcnews.com/better/ health/real-reason-going-doctor-gives-you-anxiety-ncna795566

Gremler, D. D., Van Vaerenbergh, Y., Brüggen, E. C., \& Gwinner, K. P. (2020). Understanding and managing customer relational benefits in services: A meta-analysis. Journal of the Academy of Marketing Science, 48, 565-583. https://doi.org/10.1007/s11747-019-00701-6

Habibu, S. (2020, January 10). Malaysia is top international destination for medical tourism. TheStar. https://www.thestar.com.my/news/ nation/2020/01/10/malaysia-is-top-international-destination-formedical-tourism

Hair, J. F., Anderson, R. E., Tatham, R. L., Black, W. C., Babin, B. J., \& Anderson, R. E. (2010). Multivariate data analysis. Pearson Prentice Hall.

Hair, J. F., Hollingsworth, C. L., Randolph, A. B., \& Chong, A. Y. L. (2017). An updated and expanded assessment of PLS-SEM in information systems research. Industrial Management \& Data Systems, 117(3), 442-458. https://doi.org/10.1108/IMDS-04-2016-0130

Hair, J. F., Hult, G. T. M., Ringle, C. M., \& Sarstedt, M. (2014). A primer on partial least squares structural equation modeling (PLS-SEM). Sage.

Hair, J. F., Hult, G. T. M., Ringle, C. M., Sarstedt, M., \& Thiele, K. O. (2017). Mirror, mirror on the wall: A comparative evaluation of compositebased structural equation modeling methods. Journal of the Academy of Marketing Science, 45(5), 616-632. https://doi.org/10.1007/s1174 7-017-0517-x

Hair, J. F., Matthews, L. M., Matthews, R. L., \& Sarstedt, M. (2017). PLS-SEM or CB-SEM: Updated guidelines on which method to use. International Journal of Multivariate Data Analysis, 1(2), 107-123. https://doi.org/10.1504/IJMDA.2017.10008574

Hair, J. F., Risher, J. J., Sarstedt, M., \& Ringle, C. M. (2019). When to use and how to report the results of PLS-SEM. European Business Review, 31(1), 2-24. https://doi.org/10.1108/EBR-11-2018-0203

Hair, J. F., \& Sarstedt, M. (2019). Factors versus Composites: Guidelines for choosing the right structural equation modeling method. Project Management Journal, 50(6), 619-624.

Han, H., \& Hyun, S. S. (2015). Customer retention in the medical tourism industry: Impact of quality, satisfaction, trust, and price reasonableness. Tourism Management, 46, 20-29. https://doi.org/10.1016/j. tourman.2014.06.003

Hardavella, G., Aamli-Gaagnat, A., Frille, A., Saad, N., Niculescu, A., \& Powell, P. (2017). Top tips to deal with challenging situations: doctor-patient interactions. Breathe, 13(2), 129-135. https://doi. org/10.1183/20734735.006616

Hare, C., Law, J., \& Brennan, C. (2013). The vulnerable healthcare consumer: An interpretive synthesis of the patient experience literature. International Journal of Consumer Studies, 37(3), 299-311. https://doi. org/10.1111/ijcs.12006

Henseler, J., Ringle, C. M., \& Sarstedt, M. (2015). A new criterion for assessing discriminant validity in variance-based structural equation modeling. Journal of the Academy of Marketing Science, 43(1), 115135. https://doi.org/10.1007/s11747-014-0403-8

Hoffman, A. J. (2013). Enhancing self-efficacy for optimized patient outcomes through the theory of symptom self-management. Cancer Nursing, 36(1), 16-26. https://doi.org/10.1097/NCC.0b013e3182 $4 a 730 a$

Huang, C. H., Wu, H. H., Lee, Y. C., \& Li, L. (2019). What role does patient gratitude play in the relationship between relationship quality and patient loyalty? INQUIRY: the Journal of Health Care Organization, Provision, and Financing, 56, 1-8.

Iglesias, O., Singh, J. J., \& Batista-Foguet, J. M. (2011). The role of brand experience and affective commitment in determining brand loyalty. Journal of Brand Management, 18(8), 570-582. https://doi. org/10.1057/bm.2010.58

Ippolito, A., Smaldone, F., \& Ruberto, M. (2019). Exploring patient empowerment: The link between satisfying physician relationship and patient involvement. The TQM Journal, 32(1), 92-109. https://doi. org/10.1108/TQM-04-2019-0096

Jansen, H., \& Hak, T. (2005). The productivity of the three-step testinterview (TSTI) compared to an expert review of a self-administered questionnaire on alcohol consumption. Journal of Official Statistics, 21(1), 103-120.

Jotterand, F., Amodio, A., \& Elger, B. S. (2016). Patient education as empowerment and self-rebiasing. Medicine, Health Care and Philosophy, 19(4), 553-561. https://doi.org/10.1007/s11019-016-9702-9

Kandampully, J., Zhang, T. C., \& Bilgihan, A. (2015). Customer loyalty: A review and future directions with a special focus on the hospitality industry. International Journal of Contemporary Hospitality Management, 27(3), 379-414. https://doi.org/10.1108/IJCHM-03-2014-0151

Kanter, R. M. (1977). Men and women of the corporation. Basic Books.

Kim, K. H., Kim, K. S., Kim, D. Y., Kim, J. H., \& Kang, S. H. (2008). Brand equity in hospital marketing. Journal of Business Research, 61(1), 7582. https://doi.org/10.1016/j.jbusres.2006.05.010

Kiyani, T. M., Niazi, M. R., \& Niazi, R. (2012). The Relationship between brand trust, customer satisfaction and customer loyalty: Evidence from automobile sector of Pakistan. Interdisciplinary Journal of Contemporary Research in Business, 4(1), 489-502.

Kozela, M., Pająk, A., Micek, A., Besala, A., Kubinova, R., Malyutina, S., Tamosiunas, A., Pikhart, H., Peasey, A., Nikitin, Y., Marmot, M., \& Bobak, M. (2017). Impact of perceived control on all-cause and cardiovascular disease mortality in three urban populations of Central and Eastern Europe: The HAPIEE study. Journal of Epidemiology and Community Health, 71(8), 771-778. https://doi.org/10.1136/ jech-2017-208992

Lai, K. P., \& Chong, S. C. (2020). The influence of servicescape and service credibility on older adults' intention to recover. Journal of Health Organization and Management, 34(2), 101-122. https://doi. org/10.1108/JHOM-07-2019-0215

Laine, A., Välimäki, M., Löyttyniemi, E., Pekurinen, V., Marttunen, M., \& Anttila, M. (2019). The impact of a web-based course concerning patient education for mental health care professionals: Quasiexperimental study. Journal of Medical Internet Research, 21(3), e11198.

Li, X., \& Petrick, J. F. (2010). Revisiting the commitment-loyalty distinction in a cruising context. Journal of Leisure Research, 42(1), 67-90. https://doi.org/10.1080/00222216.2010.11950195

MacKenzie, S. B., Podsakoff, P. M., \& Podsakoff, N. P. (2011). Construct measurement and validation procedures in MIS and behavioral 
reseach: Integrating new and exciting techniques. MIS Quarterly, 35(2), 293-334.

Manley, S. C., Hair, J. F., Williams, R. I., \& McDowell, W. C. (2020). Essential new PLS-SEM analysis methods for your entrepreneurship analytical toolbox. International Entrepreneurship and Management Journal, 1-21. https://doi.org/10.1007/s11365-020-00687-6

Martínez, P., \& del Bosque, I. R. (2013). CSR and customer loyalty: The roles of trust, customer identification with the company and satisfaction. International Journal of Hospitality Management, 35, 89-99. https://doi.org/10.1016/j.ijhm.2013.05.009

Matthias, M. S., Parpart, A. L., Nyland, K. A., Huffman, M. A., Stubbs, D. L., Sargent, C., \& Bair, M. J. (2010). The patientprovider relationship in chronic pain care: Providers' perspectives. Pain Medicine, 11(11), 1688-1697. https://doi. org/10.1111/j.1526-4637.2010.00980.x

Mcguckin, M., Storr, J., Longtin, Y., Allegranzi, B., \& Pittet, D. (2011). Patient empowerment and multimodal hand hygiene promotion: $\mathrm{A}$ win-win strategy. American Journal of Medical Quality, 26(1), 10-17. https://doi.org/10.1177/1062860610373138

McNeal, J. U. (1978). Consumer education as a competitive strategy. Business Horizons, 21(1), 50-56. https://doi.org/10.1016/0007-6813(78)90031-9

McShane, L., \& Sabadoz, C. (2015). Rethinking the concept of consumer empowerment: Recognizing consumers as citizens. International Journal of Consumer Studies, 39(5), 544-551.

Meesala, A., \& Paul, J. (2018). Service quality, consumer satisfaction and loyalty in hospitals: Thinking for the future. Journal of Retailing and Consumer Services, 40, 261-269. https://doi.org/10.1016/j.jretc onser.2016.10.011

Mittal, B. (1999). The advertising of services: Meeting the challenge of intangibility. Journal of Service Research, 2(1), 98-116. https://doi. org/10.1177/109467059921008

Moreira, A. C., \& Silva, P. M. (2015). The trust-commitment challenge in service quality-loyalty relationships. International Journal of Health Care Quality Assurance, 28(3), 253-266. https://doi.org/10.1108/ IJHCQA-02-2014-0017

Morgan, R. M., \& Hunt, S. D. (1994). The commitment-trust theory of relationship marketing. Journal of Marketing, 58(3), 20.

Morgeson, F. V., Hult, G. T. M., Mithas, S., Keiningham, T., \& Fornell, C. (2020). Turning complaining customers into loyal customers: Moderators of the complaint handling-customer loyalty relationship. Journal of Marketing, Vo., 84(5), 79-99. https://doi.org/10.1177/00222 42920929029

Nawawi, N. M. (2012, June 27-July 1). Evolution of public healthcare facilities designs to health trend in Malaysia: A retrospect of nation building from pre-colonial to today, $8^{\text {th }}$ World Congress on Design and Health 2012, Kuala Lumpur Convention Centre, Kuala Lumpur, Malaysia.

Nguyen, D. (2020, April 28). Traditional medicine and quest for covid-19 Cure: Covid-19 and everyday life in Southeast Asia-worried people rely on internet and traditional medicine for prevention and cures. YaleGlobal Online. https://yaleglobal.yale.edu/content/traditionalmedicine-and-quest-covid-19-cure

O'Hea, E. L., Moon, S., Grothe, K. B., Boudreaux, E., Bodenlos, J. S., Wallston, K., \& Brantley, P. J. (2009). The interaction of locus of control, self-efficacy, and outcome expectancy in relation to HbA1c in medically underserved individuals with type 2 diabetes. Journal of Behavioral Medicine, 32(1), 106-117. https://doi.org/10.1007/s1086 5-008-9188-x

Oliver, R. L. (1999). Whence consumer loyalty? Journal of Marketing, 63, 33-44.

Ouschan, R., Sweeney, J., \& Johnson, L. (2006). Customer empowerment and relationship outcomes in healthcare consultations. European Journal of Marketing, 40(9), 1068-1086. https://doi. org/10.1108/03090560610681014
Palumbo, R. (2016). Contextualizing co-production of health care: A systematic literature review. International Journal of Public Sector Management, 29(1), 72-90. https://doi.org/10.1108/ IJPSM-07-2015-0125

Paul, J., \& Sahadev, S. (2016). Service failure and problems: Internal marketing solutions for facing the future. Journal of Retailing and Consumer Services, 40, 304-311.

Podsakoff, P. M., MacKenzie, S. B., \& Podsakoff, N. (2012). Sources of method bias in social science research and recommendations on how to control it. Annual Review of Psychology, 63, 539-569. https://doi. org/10.1146/annurev-psych-120710-100452

Pranić, L., \& Roehl, W. S. (2013). Development and validation of the customer empowerment scale in hotel service recovery. Current Issues in Tourism, 16(4), 369-387. https://doi.org/10.1080/13683 500.2012.699511

Quek, D. K. L. (2014). The Malaysian Health Care System: A review. In Intensive Workshop on Health Systems in Transition. Kuala Lumpur, Malaysia: https://www.researchgate.net/publication/237409933_ The_Malaysian_Health_Care_System_A_Review

Rahman, M. K., Zailani, S., \& Musa, G. (2018). Tourists' satisfaction and loyalty intention at Shariah compliant private hospitals in Malaysia. International Journal of Tourism Sciences, 18(4), 295-311. https://doi. org/10.1080/15980634.2018.1555605

Ramayah, T., Cheah, J., Chuah, F., Ting, H., \& Memon, M. A. (2018). Partial least squares structural equation modeling (PLS-SEM) using SmartPLS 3.0. Pearson Malaysia.

Ringle, C. M., Wende, S., \& Becker, J.-M. (2015). SmartPLS 3. SmartPLS $\mathrm{GmbH}$. http://www.smartpls.com

Roddenberry, A., \& Renk, K. (2010). Locus of control and self-efficacy: Potential mediators of stress, illness, and utilization of health services in college students. Child Psychiatry \& Human Development, 41(4), 353-370. https://doi.org/10.1007/s10578-010-0173-6

Rohrer, J. E., Wilshusen, L., Adamson, S. C., \& Merry, S. (2008). Patientcentredness, self-rated health, and patient empowerment: Should providers spend more time communicating with their patients? Journal of Evaluation in Clinical Practice, 14(4), 548-551. https://doi. org/10.1111/j.1365-2753.2007.00914.x

Roter, D. (2000). The enduring and evolving nature of the patientphysician relationship. Patient Education and Counseling, 39(1), 5-15. https://doi.org/10.1016/S0738-3991(99)00086-5

Rotter, J. B. (1966). Generalized expectancies for internal versus external control of reinforcement. Psychological Monographs: General and Applied, 80(1), 1-28. https://doi.org/10.1037/h0092976

Salehi, A., Harris, N., Coyne, E., \& Sebar, B. (2016). Perceived control and self-efficacy, subjective well-being and lifestyle behaviours in young Iranian women. Journal of Health Psychology, 21(7), 1415-1425. https://doi.org/10.1177/1359105314554818

Sarker, M., Mohd-Any, A. A., \& Kamarulzaman, Y. (2021). Validating a consumer-based service brand equity (CBSBE) model in the airline industry. Journal of Retailing and Consumer Services, 59, 102354.

Sarstedt, M., Hair, J. F., Cheah, J.-H., Becker, J.-M., \& Ringle, C. M. (2019). How to specify, estimate, and validate higher-order constructs in PLS-SEM. Australasian Marketing Journal (AMJ), 27(3), 197-211. https://doi.org/10.1016/j.ausmj.2019.05.003

Schmidlen, T. J., Scheinfeldt, L., Zhaoyang, R., Kasper, R., Sweet, K., Gordon, E. S., Keller, M., Stack, C., Gharani, N., Daly, M. B., Jarvis, J., \& Christman, M. F. (2016). Genetic knowledge among participants in the Coriell personalized medicine collaborative. Journal of Genetic Counseling, 25(2), 385-394. https://doi.org/10.1007/s10897-015-9883-z

Schmidt, K., Gensichen, J., Petersen, J. J., Szecsenyi, J., Walther, M., Williams, G., \& Freund, T. (2012). Autonomy support in primary care-Validation of the German version of the Health Care Climate Questionnaire. Journal of Clinical Epidemiology, 65(2), 206-211. https://doi.org/10.1016/j.jclinepi.2011.06.003 
Seibert, S. E., Sargent, L. D., Marla, L., \& Kiazad, K. (2016). Linking developmental experiences to leader effectiveness and promotability: The mediating role of leadership self-efficacy and mentor network. Personal Psychology, 70(2), 357-397.

Senić, V., \& Marinković, V. (2013). Patient care, satisfaction and service quality in health care. International Journal of Consumer Studies, 37(3), 312-319. https://doi.org/10.1111/j.1470-6431.2012.01132.x

Sharma, N., \& Patterson, P. G. (1999). The impact of communication effectiveness and service quality on relationship commitment in consumer, professional services. Journal of Services Marketing, 13(2), 151-170. https://doi.org/10.1108/08876049910266059

Shostack, G. L. (1982). How to design a service. European Journal of Marketing, 16(1), 49-63. https://doi.org/10.1108/EUM0000000004799

Sirdeshmukh, D., Singh, J., \& Sabol, B. (2002). Consumer trust. value, and loyalty in relational exchanges. Journal of Marketing, 66(1), 15-37.

Skinner, E. A. (1996). A guide to constructs of control. Journal of Personality and Social Psychology, 71(3), 549-570. https://doi.org/10. 1037/0022-3514.71.3.549

Small, N., Bower, P., Chew-Graham, C. A., Whalley, D., \& Protheroe, J. (2013). Patient empowerment in long-term conditions: Development and preliminary testing of a new measure. BMC Health Services Research, 13(1), 1-15. https://doi.org/10.1186/1472-6963-13-263

Spence Laschinger, H. K., Gilbert, S., Smith, L. M., \& Leslie, K. (2010). Towards a comprehensive theory of nurse/patient empowerment: Applying Kanter's empowerment theory to patient care. Journal of Nursing Management, 18(1), 4-13. https://doi. org/10.1111/j.1365-2834.2009.01046.x

Stenberg, U., Haaland- Øverby, M., Koricho, A. T., Trollvik, A., Kristoffersen, L. G. R., Dybvig, S., \& Vågan, A. (2019). How can we support children, adolescents and young adults in managing chronic health challenges? A scoping review on the effects of patient education interventions. Health Expectations, 22(5), 849-862. https://doi. org/10.1111/hex.12906

Suh, M., Greene, H., Israilov, B., \& Rho, T. (2015). The impact of customer education on customer loyalty through service quality. Services Marketing Quarterly, 36(3), 261-280. https://doi.org/10.1080/15332 969.2015.1046776

Suki, N. M. (2011). Assessing patient satisfaction, trust, commitment, loyalty and doctors' reputation towards doctor services. Pakistan Journal of Medical Science, 27(5), 1207-1210.

Tan, C. N. L., Ojo, A. O., Cheah, J. H., \& Ramayah, T. (2019). Measuring the influence of service quality on patient satisfaction in Malaysia. Quality Management Journal, 26(3), 129-143. https://doi.org/10.1080/10686 967.2019.1615852

Tehseen, S., Ramayah, T., \& Sajilan, S. (2017). Testing and controlling for common method variance: A review of available methods. Journal of Management Sciences, 4(2), 142-168. https://doi.org/10.20547/jms.2014.1704202

Tengland, P. A. (2008). Empowerment: A conceptual discussion. Health Care Analysis, 16(2), 77-96. https://doi.org/10.1007/s1072 8-007-0067-3

Terho, H., \& Jalkala, A. (2017). Customer reference marketing: Conceptualization, measurement and link to selling performance. Industrial Marketing Management, 64, 175-186. https://doi. org/10.1016/j.indmarman.2017.01.005

Torres, E., Vasquez-Parraga, A. Z., \& Barra, C. (2009). The path of patient loyalty and the role of doctor reputation. Health Marketing Quarterly, 26(3), 183-197. https://doi.org/10.1080/07359680903263565

Van Den Berg, S. W., Van Amstel, F. K. P., Ottevanger, P. B., Gielissen, M. F. M., \& Prins, J. B. (2013). The cancer empowerment questionnaire: Psychological empowerment in breast cancer survivors. Journal of Psychosocial Oncology, 31(5), 565-583. https://doi. org/10.1080/07347332.2013.825361

Vargo, S. L., \& Lusch, R. F. (2004). Evolving to a new dominant logic for marketing. Journal of Marketing, 68(1), 1-17. https://doi.org/10.1509/ jmkg.68.1.1.24036
Vargo, S. L., \& Lusch, R. F. (2016). Institutions and axioms: An extension and update of service-dominant logic. Journal of the Academy of Marketing Science, 44(1), 5-23. https://doi.org/10.1007/s11747-015-0456-3

Verhoef, P. C. (2003). Understanding the effect of customer relationship management efforts on customer retention and customer share development. Journal of Marketing, 67(4), 30-45. https://doi. org/10.1509/jmkg.67.4.30.18685

Voorberg, W. H., Bekkers, V. J. J. M., \& Tummers, L. G. (2015). A systematic review of co-creation and co-production: Embarking on the social innovation journey. Public Management Review, 17(9), 1333-1357. https://doi.org/10.1080/14719037.2014.930505

Wallston, K. A., Wallston, B. S., Smith, S., \& Dobbins, C. J. (1987). Perceived control and health. Current Psychology, 6(1), 5-25. https:// doi.org/10.1007/BF02686633

Wen, B., \& Geng-qing Chi, C. (2013). Examine the cognitive and affective antecedents to service recovery satisfaction: A field study of delayed airline passengers. International Journal of Contemporary Hospitality Management, 25(3), 306-327. https://doi.org/10.1108/09596111311310991

Wieland, A., Durach, C. F., Kembro, J., \& Treiblmaier. (2017). Statistical and judgemental criteria for scale purification. Supply Chain Management: An International Journal, 22(4), 321-328.

World Health Organization. (2009). WHO Guidelines on Hand Hygiene in Health Care. First Global Patient Safety Challenge Clean Care is Safer Care. World Alliance for Patient Safety. World Health Organization Press.

Yajnik, M., Hill, J. N., Hunter, O. O., Howard, S. K., Kim, T. E., Harrison, T. K., \& Mariano, E. R. (2018). Patient education and engagement in postoperative pain management decreases opioid use following knee replacement surgery. Patient Education and Counseling, 102(2), 383387. https://doi.org/10.1016/j.pec.2018.09.001

Yin, C. Y., \& Yang, X. (2009). The impact of customer education on customer participation, functional service quality and trust in restaurant services. International Journal of Services, Economics and Management, 1(3), 233.

Zainul, E. (2018, March 1). Malaysia's healthcare industry to grow to RM80b by 2020-Frost \& Sullivan, The Edge Markets.

Zhou, W. J., Wan, Q. Q., Liu, C. Y., Feng, X. L., \& Shang, S. M. (2017). Determinants of patient loyalty to healthcare providers: An integrative review. International Journal for Quality in Health Care, 29(4), 442-449. https://doi.org/10.1093/intqhc/mzx058

Zimmerman, M. A. (2000). Empowerment theory. Psycological, organizational and community levels of analysis. In Handbook of community psychology (pp. 43-63). Plenum.

Zimmerman, M. A., Stewart, S. E., Morrel-Samuels, S., Franzen, S., \& Reischl, T. M. (2011). Youth empowerment solutions for peaceful communities: Combining theory and practice in a community-level violence prevention curriculum. Health Promotion Practice, 12(3), 425-439. https://doi.org/10.1177/1524839909357316

\section{AUTHOR BIOGRAPHIES}

Amrul Asraf Mohd-Any is a Senior Lecturer at the Department of Marketing, Faculty of Business and Accountancy, University of Malaya, Malaysia. He received his $\mathrm{PhD}$ in Business and Management (Marketing) from the University of Nottingham, UK. $\mathrm{He}$ also holds an MSc in International Hospitality Management from the University of Strathclyde in Glasgow, UK. His research lies in the area of services marketing and internet marketing, with specific focus and interest in value co-creation, customer participation and online customer engagement. His works have appeared in the Journal of Travel Research, Electronic Markets, Journal of Retailing and Consumer Services, Journal of Service Theory and Practice and the Journal of Hospitality and Tourism Management, amongst others. 
Meenatharisni Sundramohana is a Group Business Development, Marketing and Communications specialist at one of the leading private healthcare groups in Malaysia. Her fields of expertise include public relations, digital marketing, branding and consumer behaviour. She received her MBA (Marketing) from the University of Malaya, Malaysia. She also holds a Bachelor of Science degree in Medical Bioscience from Monash University, Australia. Her research interest includes health promotion, health literacy and patient experience.

Moniruzzaman Sarker is a Lecturer at the Department of Marketing, Sunway University Business School, Sunway University, Malaysia. He received his PhD in Marketing from the Faculty of Business and Accountancy, University of Malaya, Malaysia. His research interest revolves around, but are not limited to, consumer experience and behaviour, technology (IoT) in service experience, value co-creation, social media engagement, transportation services, travel and tourism services. His research works have appeared in the Journal of Retailing and Consumer Services, Journal of Hospitality and Tourism Management and Tourism Management Perspectives, amongst others.
How to cite this article: Mohd-Any, A. A., Sundramohana M., $\&$ Sarker M. (2021). Does patient empowerment matter in building loyalty? International Journal of Consumer Studies, 00, 1-23. https://doi.org/10.1111/ijcs.12718 


\section{APPENDIX A1}

\section{Measurement items}

\begin{tabular}{|c|c|c|}
\hline Constructs & Items & Measurement items \\
\hline \multirow[t]{4}{*}{ Patient education } & PE1 & My doctor keeps me up-to-date and well informed about my medical conditions \\
\hline & PE2 & My doctor explains medical terms and information in a meaningful way during consultation \\
\hline & PE3 & My doctor always offers me as much information as I need \\
\hline & PE4 & $\begin{array}{l}\text { My doctor always explains to me the pros and cons of all possible medical treatment } \\
\text { outcomes }\end{array}$ \\
\hline \multirow[t]{8}{*}{ Patient perceived control } & PC1 & I monitor my own health progress \\
\hline & PC2 & I feel responsible for managing my medical condition \\
\hline & PC3 & $\begin{array}{l}\text { I focus on managing my illness, rather than problems associated with it (e.g. financial problem, } \\
\text { family problem, relationship problem) }\end{array}$ \\
\hline & PC4 & I change my lifestyle and habits to improve my health \\
\hline & PC5 & I know what triggers the symptoms of my medical condition \\
\hline & PC6 & I actively check for warning signs that trigger my medical condition \\
\hline & PC7 & I have control over the symptoms of my medical condition \\
\hline & PC8 & My doctor encourages me to take responsibility of my own health \\
\hline \multirow[t]{14}{*}{ Doctor support } & DS1 & My doctor provides me with choices and options for treatment \\
\hline & DS2 & My doctor understands my medical condition well \\
\hline & DS3 & My doctor allows me to be open during consultations \\
\hline & DS4 & My doctor conveys confidence in my ability to make healthier changes \\
\hline & DS5 & My doctor supports me for who I am \\
\hline & DS6 & My doctor ensures that I understand about my medical condition \\
\hline & DS7 & My doctor encourages me to ask questions \\
\hline & DS8 & My doctor answers my questions responsively \\
\hline & DS9 & I feel very good about the way my doctor talks to me \\
\hline & DS10 & My doctor listens to my opinions \\
\hline & DS11 & My doctor handles my emotions very well \\
\hline & DS12 & My doctor cares about me as a patient \\
\hline & DS13 & My doctor tries to understand my point of view before suggesting a new way to do things \\
\hline & DS14 & I am able to share my feelings with my doctor \\
\hline \multirow[t]{5}{*}{ Patient participation } & PP2 & I ensure my medication is always accessible \\
\hline & PP5 & I ask a lot of questions during consultation with my doctor \\
\hline & PP6 & I guide my doctor on the symptoms that need to be addressed \\
\hline & PP7 & I provide input about my choice of treatment to my doctor \\
\hline & PP8 & I openly inform my doctor about my concerns and worries \\
\hline \multirow[t]{4}{*}{ Patient trust in doctor } & PT1 & I trust my doctor at all times \\
\hline & PT2 & My doctor is honest and truthful \\
\hline & PT3 & I can count on my doctor to do what is right for me \\
\hline & PT4 & I have confidence in my doctor \\
\hline \multirow[t]{5}{*}{ Relationship commitment } & $\mathrm{RC} 1$ & I want to maintain the relationship with my doctor in the future \\
\hline & $\mathrm{RC} 2$ & I am very committed to my doctor \\
\hline & $\mathrm{RC} 3$ & The relationship I have with my doctor deserves all my effort to maintain it \\
\hline & $\mathrm{RC} 4$ & Even if I have new options, I would still visit this doctor \\
\hline & $\mathrm{RC5}$ & If somebody disapproves of my doctor, I would emphasise on his/her positive traits \\
\hline \multirow[t]{3}{*}{ Patient loyalty to doctor } & PL1 & If there is a need to seek medical advice, I will think of this doctor first \\
\hline & PL2 & If there is a need to seek medical advice, this doctor will be my first choice \\
\hline & PL3 & I feel that I am a loyal patient to this doctor \\
\hline
\end{tabular}




\section{International Journal of Consumer Studies}

\begin{tabular}{lll}
\hline Constructs & Items & Measurement items \\
$\begin{array}{lll}\text { Workplace compensation- } \\
\text { measured latent marker }\end{array}$ & MV1 & I try to let others know about my knowledge and skills \\
variable (MLMV) & MV2 & I am more careful about how I present myself to others \\
& MV3 & I try to make my accomplishments visible to my networks \\
& MV4 & I take opportunities to demonstrate my special skills and abilities to others \\
\hline
\end{tabular}

